\title{
Brains, Bodies, Selves, and Science: Anthropologies of Identity and the Resurrection of the Body
}

\author{
Fernando Vidal
}

\section{A Desire for Dead Bodies}

Before Dante leaves the fourth heaven, that of the sun, inhabited by the souls of the wise, Beatrice formulates for him what he desires to know yet would say neither with his voice nor with his thought. Will the light with which the disembodied souls blossom remain with them eternally and, if so, will it not harm their sense of sight after they regain their bodies? ${ }^{\text {? Solo- }}$ mon's answer-a "modest voice" coming forth from a "most divine light"is that, as burning coal outshines fire, resurrected bodies will outshine disembodied souls; but their light will cause them no fatigue because their organs "will be strong for everything that can bring them delight" ( $P$, bk. 14, 1l. 43-46, p. 187). At resurrection, our person will be all the more perfect

Research for this article and related work in progress has been supported by a John Simon Guggenheim Memorial Fellowship and a grant from the Swiss National Science Foundation. Earlier versions were discussed at the Max Planck Institute for the History of Science (Berlin) and at the History of the Human Sciences Workshop of the Morris Fishbein Center for the History of Science and Medicine (University of Chicago). I have profited greatly from comments, questions, and criticisms, especially from Lorraine Daston, Jan Goldstein, Robert Proctor, Robert Richards, and Patrick Singy.

Unless otherwise indicated, all translations are my own.

1. Dante Alighieri, Paradiso, vol. 3 of La divina commedia, ed. Natalino Sapegno (Florence, 1985), bk. 14, 11. 13-18, p. 185; hereafter abbreviated P. According to Thomas Aquinas, the resurrected body will shine more brightly than the sun, which burns the eye. Yet, because its light will emanate from the soul, it will only give pleasure to the blessed. See Thomas Aquinas, Summa theologica, trans. Fathers of the English Dominican Province, 5 vols. (Westminster, Mar., 1981), suppl. QQ. 85, art. 2, 5:2914. For Dante, virtually the entire experience of paradise is a confrontation with unbearable light—-battaglia de' debili cigli" ( $P$, bk. 23, 1. 78, p. 294). The poet even suffers temporary blindness when he tries to see through the light that emanates from Saint John's soul in order to see the saint's body, which according to legend had ascended directly to Paradise; see $P$, bk. 25, pp. 314-25.

Critical Inquiry 28 (Summer 2002)

(C) 2002 by The University of Chicago. 0093-1896/02/2804-0006 $\$ 10.00$. All rights reserved. 
as the soul and the body are reunited. The resurrected, "glorious" body of the blessed will be adapted to the state of beatitude, apt to rejoice in the "beatific vision." 2 Delight or pleasure, explains Aquinas, is not required for beatitude. Nevertheless, in the same way that the grace of youth results from youth itself, pleasure is a concomitant of the beatific vision. ${ }^{3}$ The glorious body will be prepared for it.

As they hear Solomon describe their future embodied state, the choruses of souls cry out "Amen!"- "Thus be it!" Dante sees therein an expression of the souls" "desire for dead bodies" ( $P$, bk. 14, l. 63, p. 188). A disembodied soul, Solomon implies, is not a person. And, yet, is there not a contradiction in the assertion that bliss as visio Dei necessitates the flesh, that perfection for eternity requires a corporeal existence? Early Christian theologians did not fail to see the problem their religion had set forth. ${ }^{4}$

Saint Augustine asserted that the human intellectual soul cannot see God's substance the way angels do and speculated that such inferiority results from the soul's "natural appetite" to govern the body. Desiderium or inclinatio ad corpus prevents the soul from fully aspiring toward God as long as it is not in control of the body. ${ }^{5}$ Is, then, a body necessary for the beatific vision, and what difference would it make? Following Augustine, Bernard of Clairvaux insisted that there is no perfect beatitude before resurrection; after death, souls remain "linked to the body" — not by animal life or sensation, but by a sort of natural attachment - to the point of neither willing nor being able to realize themselves without the body. ${ }^{6}$ Aquinas, on the contrary, maintained that disembodied souls can enjoy the beatific vision and that such vision is as intense (that is, qualitatively the same) before as after the resurrection of the flesh. Yet, insofar as the soul desires its body, be-

2. Beatitude, or beatific vision, is the reward of the blessed and the ultimate end of the human being. It is the operation whereby the intellectual soul "sees" the divine essence; by means of such visio Dei, the intellect reaches the essence of its own first cause, thus becoming perfect through union with God; see Aquinas, Summa theologica, 1a-2ae, Q. 1-3, 2:583-602. "For now we see through a glass, darkly; but then face to face" (1 Cor. 13:12).

3. See Aquinas, Summa theologica, 1a-2ae, Q. 4, art. 1-2, 2:604.

4. On this question, especially in Bonaventure and Peter Lombard, see Caroline Walker Bynum, The Resurrection of the Body in Western Christianity, 200-1336 (New York, 1995), pp. 247-55.

5. See Saint Augustine, De Genesi ad litteram [The Literal Meaning of Genesis], trans. John Hammond Taylor, vols. 41-42 of Ancient Christian Writers: The Works of the Fathers in Translation, ed. Johannes Quasten, Walter J. Burghardt, and Thomas Comerford Lawler (New York, 1982), vol. 2, bk. 12, chap. $35, \$ 68$, pp. 228-29.

6. Bernard de Clairvaux, Liber de diligendo Deo, trans. Françoise Callerot et al., under the title L'Amour de Dieu, vol. 29 of Oeuvres complètes (Paris, 1993), 11.30, pp. 136, 137.

FER A N D O VID A L is professor at the Max Planck Institute for the History of Science in Berlin and the author of Piaget before Piaget (1994). 
atitude is extended (that is, quantitatively) after the reunion of soul and body. ${ }^{7}$ Its plenitude, then, still requires the body, which is why the disembodied souls of Dante's Paradise desire their dead bodies in the first place.

Dante, however, suggests that souls' desire for embodiment concernsless their own carnal existences than those of their mothers and their beloveds:

Tanto mi parver subiti e accorti

e l'uno e l'altro coro a dicer "Amme!"

che ben mostrar disio d'i corpi morti;

forse non pur per lor, ma per le mamme,

per li padri e per li altri che fuor cari

anzi que fosser sempiterne fiamme. ${ }^{8}$

Far from being, as has been said, the most childish, light, and tender hypothesis of the entire Divine Comedy, the words "maybe not for themselves" ( forse non pur per lor) point to specifically theological questions Dante knew well. ${ }^{9}$ The whole of humankind will resurrect, but, it was asked, are the others necessary for each person's beatitude? Augustine declared that, in order to be wise and happy, the only assistance a spiritual and intellectual creature needs is the inner help conveyed by the Creator's eternity, truth, and charity; nevertheless, such creatures will perhaps see each other and rejoice together "joined in one society with God." ${ }^{10}$ For Aquinas, a societas amicorum might contribute to the accomplishment of beatitude; nonetheless, the essential glory of the beatific vision resides in God, not in humanity. ${ }^{11}$

Theological matters do not exhaust Dante's rendering of the souls' "desire for dead bodies." The distinction of "mamas" and "fathers" and their proximity to "desire" result from a deliberate choice. In De vulgari eloquentia, the poet had classed mamma among the puerilia (childish words), characterized by their "simplicity," and disio among the pexa, trisyllables that convey a sense of suavitas, sweetness and pleasure. ${ }^{12}$ The contrast between mamme and padri is somewhat diminished by the enveloping tonal

7. See Aquinas, Summa theologica, 1a-2ae, Q. 4, art. 6, 2:606-7.

8. "So prompt and eager seemed to me one chorus and the other to say 'Amen!' that well they showed desire for dead bodies - maybe not for themselves, but for the mamas, the fathers and the others dear to them before becoming imperishable flames" ( $P$, bk. 14, 1l. 61-66, p. 188).

9. See Vittore Sermonti, Il Paradiso di Dante, ed. Cesare Segre (Milano, 1993), p. 231.

10. Augustine, De Genesi ad litteram, bk. 8, chap. $25, \$ 47$, p. 66.

11. See Aquinas, Summa theologica, 1a-2ae, Q. 4, art. 8, 2:608.

12. Dante, De vulgari eloquentia, trans. and ed. Steven Botterill (Cambridge, 1996), bk. 2, chap. 7 , pp. 66, 68, 69. Pexus, said primarily of "neatly combed" hair, also qualifies a well-groomed person or a softly and densely hairy, silky, or wooly garment; its opposite is hirsutus, shaggy, rough, coarse, unkempt. 
quality of disio but reinforced by a hierarchy of objects of love: moms, fathers, and the rest of the beloved. In the fourteenth book of Paradiso, waiting for the resurrection entails longing for body, above all the mother's. Bodies, therefore, are not mere adjuncts to the visio Deibut instruments of another vision, that of the persons the blessed loved before death reduced them all to disembodied souls. ${ }^{13}$ Restored flesh gives beatitude its fullness, especially as it allows communion with the mother. It may well be that in Christianity, "the body scorned ... is a female body." ${ }^{14}$ But it is no less true that mystics ecstatically experienced Christ as a lactating mother ${ }^{15}$ and that, three centuries after Dante, François de Sales extended earlier visions of God's motherhood to beatitude by describing it, in intensely carnal language, as feeding at the mother's breast. ${ }^{16}$

This would be fertile ground for psychoanalysis. According to Freud, we are unconsciously convinced of our immortality, and beliefs about the afterlife are a compromise that allows us to accept death by denying its power of annihilation. ${ }^{17}$ The structure of such compromise is dictated by the newborn's state of absolute dependence. Like other religious representations, the afterlife is shaped by memories of childhood and the human species, as a way of enduring our original helplessness. ${ }^{18} \mathrm{Had}$ Freud interpreted book fourteen of Paradise, he would have related Dante's mamme to his notion

13. Beyond requirements of plot, style, and figurability, the fiction of body-shaped souls in Inferno and Purgatorio is a way of asserting the ontological necessity of body. See Bynum, "Faith Imagining the Self: Somatomorphic Soul and Resurrection Body in Dante's Divine Comedy," in Faithful Imagining: Essays in Honor of Richard R. Niebuhr, ed. Sang Hyun Lee, Wayne Proudfoot, and Albert Blackwell (Atlanta, 1995), pp. 81-104.

14. Margaret R. Miles, Carnal Knowing: Female Nakedness and Religious Meaning in the Christian West (Boston, 1989), p. 185.

15. See Bynum, Jesus as Mother: Studies in the Spirituality of the High Middle Ages (Berkeley, 1982), esp. chap. 4.

16. In Heaven, he wrote, God will be united to our intellect without the intermediary of representation; we shall be

comme des enfants très heureux... nourris de la propre substance divine, reçue en notre âme par la bouche de l'entendement; et ce qui surpasse toute douceur, c'est que, comme les mères ne se contentent pas de nourrir leurs poupons de leur lait ... si elles-mêmes ne mettent le chicheron de leur tétin dans leur bouche... en sorte que cette substance maternelle serve de tuyau aussi bien que de nourriture ... ainsi Dieu, notre Père, ne se contente pas de faire recevoir sa propre substance en notre entendement ... mais par un abîme de sa douceur il appliquera lui-même sa substance à notre esprit.

[Saint François de Sales, Traité de l'amour de Dieu (1616), Oeuvres, ed. André Ravier and Roger Devos (Paris, 1969), bk. 3, chap. 11, pp. 513-14]

17. Sigmund Freud, “Thoughts for the Times on War and Death" (1915), The Standard Edition of the Complete Psychological Works of Sigmund Freud, trans. and ed. James Strachey, 24 vols. (London, 1953-74), 14:273-302; see esp. chap. 2.

18. See Freud, The Future of an Illusion, trans. and ed. Strachey (New York, 1975), see esp. chap. 4 . 
of the mother as the child's first object of love and protector against anxiety. Fond as he was of reading his theories into past authors, he would have praised the poet's psychological penetration. But he would have undoubtedly stuck to his conviction that religious notions are only "illusions, fulfilments of the oldest, strongest and most urgent wishes of humanity." ${ }^{19}$ Frustrated on earth, we invent the afterlife as the spatial and temporal framework where our desires can be finally realized.

In a Freudian perspective, these lines from Paradise move us because we unconsciously recognize our deceptive defense against reality and our mothers' initial protective role. More positively, as a late eighteenth-century materialist philosopher-physician put it, the desire and hope of a future life derive not only from narrowly personal expectations but also from "the noblest feelings of the human heart" - to be again with our loved ones and to witness the full realization of justice and virtue. ${ }^{20}$ In either case, why not? I suspect few of us are like Thomas More's utopians who, convinced that they would be infinitely happy in the afterlife, neither lament nor fear death. Most of us sometimes do both; and considerable numbers are also concerned about the hereafter. Beyond eschatology and anxiety, however, the central problem of the Christian discourse about the resurrection is personal identity and particularly the relationship between self and body.

In the Divine Comedy, to be a person requires the union of soul and body. Personhood is not exclusively psychological; as highlighted by the adjective dead in corpi morti, a soul does not desire simply to have a body but to recover the one to which it had been joined. Body and desire are at the heart of personal identity and together tend toward the accomplishment of human perfection. Both, moreover, call for other presences. Each person's completeness necessitates love, especially the kind whose model is, for Freud, the child's relationship to the mother. In the Platonic view, souls, before reincarnation, drink from the river of forgetfulness: "In Lethe's lake they long oblivion taste." ${ }^{21}$ Immediately, they surrender their past lives and identities:

Lethe the River of Oblivion rolls

Her wat'ry Labyrinth, whereof who drinks,

Forthwith his former state and being forgets,

Forgets both joy and grief, pleasure and pain. ${ }^{22}$

19. Ibid., p. 38 .

20. Pierre-Jean-George Cabanis, "Lettre à M. F. sur les causes premières" (ca. 1806-07), Oeuvres philosophiques de Cabanis, ed. Claude Lehec and Jean Cazeneuve, 2 vols. (Paris, 1956), 2:267.

21. Vergil, Vergil's "Aeneid" and Fourth ("Messianic") Eclogue in the Dryden Translation, ed. Howard Clarke (University Park, Penn., 1989), bk. 6, 1. 715, p. 169.

22. John Milton, Paradise Lost, ed. John Leonard (London, 2000), bk. 2, 11. 583-86, p. 39. 
The Christian requirements for an afterlife are just the opposite of metempsychosis. Souls are not persons; life after death necessitates the original body; and death is not the joyful liberation of soul from a prison of flesh but the disruption of the original unity of the human being.

This is consistent with Christian attitudes to the body. Although there was no celebration of the body per se at the expense of the soul, redemption included both, and the Church consistently condemned the decrying of matter and the denigration of the human body. ${ }^{23}$ Ascetic practices were seen as ways to prepare the body to receive the spirit of God. Even a writer in the Platonic tradition, such as Gregory of Nyssa in the fourth century, "was concerned less with the heaviness of the body than with the tight knot of anxieties that had gathered within the soul itself. ... The true 'plunge' that accounted for the misery of the human condition was not that of the soul into the body; it was the plunge of the human person, body and soul together, into the present, fallen state of society." ${ }^{24}$ For him, the goal of the virgin life was not the repression of the sexual drive but "the withering away in the human heart of the sense of time placed there by the fear of death." ${ }^{25}$ In general, a supposedly repressive and flesh-hating practice such as permanent sexual renunciation was a way of living the body as a "temple of the Holy Spirit" (1 Cor. 6:19) and preparing it to be like the body of the risen Christ. ${ }^{26}$

\section{Personal Identity and the History of the Body}

My goal is not to comment on Dante or examine the theology of resurrection. Rather, I wish to explore how discussions on the resurrection of the body may function as a fil conducteur for a history of notions of personal identity. As is clear from historical and anthropological studies, "modern identity" - characterized by radical reflexivity, a sense of inwardness, a firstperson standpoint, and disengagement from body and world-would have been incomprehensible for people in the past or other cultures. ${ }^{27}$ We "have"

23. See Frank Bottomley, Attitudes to the Body in Western Christendom (London, 1979), esp. pp. 157-6o and the overview of conciliar documents, pp. 233-34 n. 8.

24. Peter Brown, The Body and Society: Men, Women, and Sexual Renunciation in Earlier Christianity (New York, 1988), p. 301.

25. Ibid., p. 298.

26. This is not to deny that there were indeed harsh condemnations of the flesh, as well as practices that can be interpreted in terms of repression (as, for example, Jacques Sole does consistently in L'Amour en Occident à l'époque moderne; see Jacques Solé, L'Amour en Occident à l'époque moderne [Paris, 1976], esp. pp. 85-150); yet, as highlighted in Michel Foucault's La Volonté de savoir, the "repressive hypothesis" is vastly insufficient. See Michel Foucault, La Volonté de savoir, vol. 1 of Histoire de la sexualité (Paris, 1976).

27. I have followed Charles Taylor, Sources of the Self: The Making of the Modern Identity (Cambridge, Mass., 1989) for the characterization of "modern identity." 
bodies only in the perspective of the post-Lockean possessive individualism that makes us their owners; objectified and distanced from our "selves," our bodies are for us things we own, not entities we are. This observation, however, should not prevent us from talking, without anachronism, about self, identity, individual, or person and to try to understand the sources of the modern identity and what other peoples, past or present, consider essential in order to ask and investigate the question, Who am I? ${ }^{28}$

During the seventeenth and eighteenth centuries, the terms of resurrection debates were altered and, at the intersection of philosophy, theology, the life sciences, and psychology, participated in the emergence of new ways of thinking about the relation between persons and bodies. The study of these transformations helps trace the emergence of the presently dominant cognitivist, brain-based idea of personal identity and thus supports both a critique of the self-as-brain philosophy and a formulation of more phenomenological and experiential apprehensions of what it is to be human.

Problematic as it was and remains, the doctrine of bodily resurrection contradicts the dualistic understanding of the history of body and the self in the Christian West. Christianity is supposed to see the individual as a duality, torn between an immortal soul to be elevated and redeemed and a perishable body to be mortified and despised. Nevertheless, from an anthropological point of view, it holds the opposite of Descartes's fiction of a bodyless self. ${ }^{29}$ The idea that, for the Christian tradition, "being human meant being an embodied mind" is inaccurate. ${ }^{30}$ The common expression "embodied self" involves the idea of a (potentially) disembodied self. Christianity, however, rejects the possibility of a person existing otherwise than as a composite of body and soul. As Ludwig Feuerbach angrily remarked in 1846 ,

Seligkeit ist das letzte Wort der Religion und Theologie. Aber was ist Seligkeit? Sinnlichkeit als Objekt der Phantasie und des Gemüts. Die Behauptung, daß das Christentum nur eine geistige Seligkeit wolle, is eine schamlose Lüge der modernen Heuchler oder Ignoranten. Das

28. See for example The Category of the Person: Anthropology, Philosophy, History, ed. Michael Carrithers, Steven Collins, and Steven Lukes (Cambridge, 1985); see also, as well as Taylor, Sources of the Self, esp. part 2.

29. “Ie me considereray moy-mesme comme n'ayant point de mains, point d'yeux, point de chair, point de sang, comme n'ayant aucuns sens, mais croyant faussement auoir toutes ces choses" (René Descartes, première méditation, Méditations sur la philosophie première [1641], Oeuvres de Descartes, ed. Charles Ernest Adam and Paul Tannery [1896-1909; Paris, 1982], 9.1:18).

30. See Roy Porter, "History of the Body," in New Perspectives on Historical Writing, ed. Peter Burke (University Park, Penn., 1991), p. 212; see also Porter, "Bodies of Thought: Thoughts about the Body in Eighteenth-Century England," in Interpretation and Cultural History, ed. Joan H. Pittock and Andrew Wear (New York, 1991), pp. 82-108. 
Christentum unterschied sich gerade dadurch von dem philosophischen Heidentume ... daß es eine fleischliche, d. i. sinnliche, Seligkeit und Unsterblichkeit als letztes Ziel und Wesen des Menschen aussprach. ${ }^{31}$

In the calmer words of a contemporary theologian, a person "is not someone who has a body but whose existence is corporeal"; as suggested by the doctrine of the resurrection of the flesh, "the body is the whole man." 32

Today, from artistic avant-gardes to popular self-help and personal development manuals, the body is omnipresent. The human sciences ponder the construction of bodies and the practices and discourses that govern them; body history is a blooming field. ${ }^{33}$ In contrast, the academic philosophy of personal identity often reduces, if only by way of a speculative exercise, the body to the brain. ${ }^{34}$ Most puzzle cases used to think about identity

31. "Beatitude is the last word of religion and theology. But what is beatitude? Sensibility as the object of phantasy and feelings. The assertion that Christianity wants only a spiritual beatitude is a shameless lie of modern hypocrites or ignoramuses. Christianity differentiates itself from philosophical paganism ... precisely in that it formulates a carnal, i.e. a sensible beatitude and immortality as ultimate end and essence of humanity" (Ludwig Feuerbach, "Wider den Dualismus von Leib und Seele, Fleisch und Geist" [1846], Gesammelte Werke, ed. Werner Schuffenhauer [Berlin, 1989], 10:147). The whole text is a forceful manifesto against propositions such as "Ich unterscheide mich von meinem Leibe" (p. 140), against the notion that "we" can differentiate ourselves from our body or our brain otherwise than by a logical or "imaginary" operation.

32. Antoine Vergote, “The Body as Understood in Contemporary Thought and Biblical Categories” (1979), trans. Mark Muldoon, Philosophy Today 35 (1991): 96, 97. See also Gedaliahu G. Stroumsa, "Caro salutis cardo: Shaping the Person in Early Christian Thought," History of Religions 30 (1990): 25-50. For recent discussions of these issues: James F. Keenan, "Christian Perspectives on the Human Body," Theological Studies 55 (June 1994): 330-46, and Bynum, "Why All the Fuss about the Body? A Medievalist's Perspective," Critical Inquiry 22 (Autumn 1995): 1-33.

33. See for example Fragments for a History of the Human Body, ed. Michel Feher, Ramona Naddaff, and Nadia Tazi, 3 vols. (New York, 1989); Arthur W. Frank, "For a Sociology of the Body: An Analytical Review," in The Body: Social Process and Cultural Theory, ed. Mike Featherstone, Mike Hepworth, and Bryan S. Turner (London, 1991); and Margaret Lock, "Cultivating the Body: Anthropology and Epistemologies of Bodily Practice and Knowledge," Annual Review of Anthropology 22 (1993): 133-55. On the neural, immunological, genetic, and phenotypic bodies and their politico-scientific contexts, see Scott F. Gilbert, "Resurrecting the Body: Has Postmodernism Had Any Effect on Biology?" Science in Context 8 (Winter 1995): 563-77. For useful samples of approaches and themes, see Gepeinigt, begehrt, vergessen: Symbolik und Sozialbezug des Körpers im späten Mittelalter und in der frühen Neuzeit, ed. Klaus Schreiner and Norbert Schnitzler (Munich, 1992); Disciplina dell'anima, disciplina del corpo e disciplina della società tra medioevo ed età moderna, ed. Paolo Prodi (Bologna, 1994). For recent studies about the "embodiment of knowledge," see Science Incarnate: Historical Embodiments of Natural Knowledge, ed. Christopher Lawrence and Steven Shapin (Chicago, 1998). For a valuable discussion of conceptual and methodological tensions within body history today, see Philipp Sarasin, "Mapping the Body: Körpergeschichte zwischen Konstruktivismus, Politik und 'Ehrfahrung," Historische Anthropologie 7, no. 3 (1999): 437-51.

34. See, for a synthetic presentation, Harold W. Noonan, Personal Identity (London, 1989); for a useful anthology, see Personal Identity, ed. John Perry (Berkeley, 1975). See also Stephane Ferret, Le 
imply that only the brain is truly indispensable, and that seems validated by the cognitive neurosciences. If the brain of person $\mathrm{A}$ is transplanted into the body of person $\mathrm{B}$, then $\mathrm{A}$ undergoes a body transplant, rather than $\mathrm{B}$ a brain transplant..$^{35}$ This is a simple situation compared to the cases of fission in which each hemisphere is transplanted into a different body. Apparently, we can do without the rest of the body; in fact, "I am my brain." ${ }^{36}$ In spite of its apparent abstraction, the neurophilosophical reduction of self touches upon momentous medical and bioethical debates about the beginning and the end of life.

As a consequence of the development of resuscitation techniques in the 1960 s, the total cessation of heart and respiratory functions became insufficient as a criterion of death. Those functions could be artificially prolonged after the destruction of the relevant portions of the brain or revived in cases of limited damage. Thus evolved the definition of brain death. But which are the functions or regions of the brain whose destruction entails death? In theory, death implies the definitive cessation of the functions of the whole brain. In practice, however, the patient's personality, memory, judgment, reasoning, and capacities for conscious feeling and thinking are recognized as the functions whose end signals the death of a human person. Since the mid-1970s, under the name of cortical or cognitive death, some theoreticians have proposed to confirm such practice and redefine death as the irreversible halt of the capacity to be conscious. ${ }^{37}$ The proposal extends to the definition of life. Indeed, a notion of human life symmetrical to cortical death would specify the brain structures that demarcate the embryo from the person..$^{38}$ The onset and the end of a human person's life and death would depend on the existence or adequate functioning of certain portions of the brain.

Philosophe et son scalpel: Le Problème de l'identité personnelle (Paris, 1993), which emphasizes the place of the brain.

35. Such an operation, of course, is not (yet?) feasible, but some individuals already protect themselves against it. The text of an older version of the Swisstransplant cards carried by potential organ donors explicitly excluded the brain and the organs of reproduction. Individual identity was thus doubly preserved for both the donors and for those persons whose identity would be partly defined by the fact of being their descendants.

36. Thomas Nagel, The View from Nowhere (New York, 1986), p. 40. Nagel describes this hypothesis of the brain's indispensability as a "mild exaggeration."

37. See Robert M. Veatch, "The Impending Collapse of the Whole-Brain Definition of Death," Hastings Center Report 23 (July-Aug. 1993): 18-24. See also Death: Beyond Whole-Brain Criteria, ed. Richard M. Zaner (Dordrecht, 1988); Ronald E. Cranford and David Randolph Smith, "Consciousness: The Most Critical Moral (Constitutional) Standard for Human Personhood," American Journal of Law and Medicine 13, no. 2-3 (1987): 233-48; and the critique by Mario Moussa and Thomas A. Shannon, "The Search for the New Pineal Gland: Brain Life and Personhood," Hastings Center Report 22 (May-June 1992): 30-37.

38. Hans-Martin Sass, "Brain Life and Brain Death: A Proposal for a Normative Agreement," Journal of Medicine and Philosophy 14, no. 1 (1989): 45-59. 
The reduction of self to consciousness as a function of soul or brain is a relatively late development. Only in the seventeenth century, under the influence of Cartesian metaphysics, did emphasis on psychosomatic unity shift to the unity of mind, the latter becoming the definitory element of identity. ${ }^{39}$ Throughout the eighteenth century, the seat of the soul was sought within the brain. The notion of a seat of the soul did not imply the existence of an organ that was the soul but rather that of a structure where body and soul would interact and operate the synthesis of sensations, knowledge, and memory that constitute the foundation of personal identity. Starting at the beginning of the nineteenth century, the quest for a seat of the soul was replaced by research on cerebral localizations and, later, cerebral functions. ${ }^{40}$ The questions left unresolved in the problem area of soulbody relations are dealt with by neuroscientific investigations into the mind-brain. ${ }^{41}$ By the late twentieth century, the discourses and interests surrounding these investigations had turned the brain into a major fetish of Western cultures. ${ }^{42}$ Extending toward the present the work of Caroline Bynum, the history of postmedieval debates about the resurrection of the body sketched here highlights these processes of disembodiment and neuropsychologization of personal identity. ${ }^{43}$

\section{The Christian Tradition}

Inseparable from the mystery of the Incarnation-the Christ as God made flesh—the resurrection of the dead is the main promise and hope of

39. See Ben Lazare Mijuskovic, The Achilles of Rationalist Arguments: The Simplicity, Unity, and Identity of Thought from the Cambridge Platonists to Kant: A Study in the History of an Argument (The Hague, 1974), esp. chap. 4.

40. On the seat of the soul, see Edwin Clarke and L. S. Jacyna, Nineteenth-Century Origins of Neuroscientific Concepts (Berkeley, 1987); Max Neuburger, The Historical Development of Experimental Brain and Spinal Cord Physiology before Flourens (1897), trans. and ed. E. Clarke (Baltimore, 1981). Béla Révész, Geschichte des Seelenbegriffes und der Seelenlokalisation (1917; Amsterdam, 1966) is still useful. On the passage from the brain as organ of the soul to the problem of cerebral localization, see Michael Hagner, Homo cerebralis: Der Wandel vom Seelenorgan zum Gehirn (Berlin, 1997), chaps. 1 and 2.

41. A good synthesis is furnished by Jean-Noël Missa, L'Esprit-cerveau: La Philosophie de l'esprit à la lumière des neurosciences (Paris, 1993).

42. See Michael Hagner and Cornelius Borck, "Brave Neuro-Worlds," Neue Rundschau 110, no. 3 (1999): 70-88.

43. Bynum - to whose work mine is deeply indebted — has renewed the history of the doctrine of the resurrection of the body by emphasizing its link with questions of personal identity and contemporary issues. See Bynum, "Material Continuity, Personal Survival, and the Resurrection of the Body: A Scholastic Discussion in Its Medieval and Modern Contexts," Fragmentation and Redemption: Essays on Gender and the Human Body in Medieval Religion (New York, 1992) and The Resurrection of the Body. With one exception and the Lockean studies cited below (notes 72 and 81 ), there is to my knowledge no detailed historiography on resurrection debates after Aquinas. 
the Christian religion. ${ }^{44}$ "Now if Christ be preached that he rose from the dead, how say some among you that there be no resurrection of the dead? But if there is no resurrection of the dead," Saint Paul told the Corinthians, "then Christ is not risen: and if Christ be not risen, then is our preaching vain, and your faith is also vain" (1 Cor. 15:12-14). From the beginning of Christianity to the most recent Roman Catholic catechism (1992) and beyond, the doctrine has ranked among the mysteries of faith. ${ }^{45}$ To the extent that all we can know about it has been communicated by Revelation, it is superfluous, as Malebranche put it, "de faire sur cela mille questions de physique et de métaphysique." 46 Yet that is precisely what generations of theologians, philosophers, and naturalists have done as they tried to understand the conditions of resurrection, the continuity of the terrestrial and the resurrected body, and the relation between body and person.

According to established doctrine, the bodily and psychological identity of resurrected individuals will be the same as that of the persons they were while alive. Identity, in the sense of the Latin ipse, necessitates sameness, in the sense of $i d e m .{ }^{47}$ The reason why the doctrine of the resurrection is so deeply involved with the problem of identity lies in the paradoxical assertion that our resurrected bodies will be spiritual and yet numerically identical (idem numero) to the the bodies of flesh we possessed during our life on earth. ${ }^{48}$ Here we have an organism that changes and yet, somehow, remains

44. Oscar Cullmann went as far as maintaining that belief in the immortality of the soul was a Platonizing import into a primitive Christian faith focused on the resurrection of the dead. See Oscar Cullmann, Immortalité de l'âme ou Résurrection des morts? Le Témoignage du Nouveau Testament (Neuchâtel, 1956).

45. This chronological range points to the meaning of tradition in relation to what I here present as Christian theological and anthropological views. The Roman Catholic Church considers that there exist revealed truths apart from those contained in the Bible. These truths are formulated and elucidated in oral traditions, in the Gospels, and in theological writings. In expounding them in its official documents, the Church exerts its teaching authority or magisterium. As highlighted by the extensive scholarly apparatus characteristic of such documents, the magisterium is based on past texts, treated so as to bring about continuity of content and interpretation. That tradition in this sense results from polemics and struggles, anathema and excommunication, does not alter its function. To it belong both the doctrine of the resurrection of the same carnal body and the view that there is no such a thing as a "disembodied self."

46. Such is Théodore's opinion in the third conversation of "Entretiens sur la mort," Entretiens sur la métaphysique, sur la religion et sur la mort (1711), in Nicolas Malebranche, Oeuvres, ed. Geneviève Rodis-Lewis, 2 vols. (Paris, 1992), 2:1038.

47. Ipse denotes a person or thing of which something is exclusively predicated and can therefore stand for the reflexive pronoun; idem is used when two predicates are referred to the same subject or as a word of comparison ("the same as ...").

48. "Numerically identical": if we bathe in a river, the water in which we swim remains only qualitatively, not numerically the same. In De principiis naturae, Aquinas's example for things that are numerically the same is "Socrates and this man, Socrates being pointed out" (quoted in Joseph Bobik, Aquinas on Matter and Form and the Elements: A Translation and Interpretation of the "De Principiis Naturae" and the "De Mixtione Elementorum" of St. Thomas Aquinas [South Bend, Ind., 
the same. The aptness of Saint Augustine's formulation has never been surpassed:

Hence the spiritual flesh will be subject to spirit, but it will still be flesh, not spirit; just as the carnal spirit was subject to the flesh, but was still spirit, not flesh.... And the man who is called spiritual in this life is still carnal in respect to his body.... But he will be spiritual in respect to his body as well when the same flesh is raised so as to fulfil the Scripture: "It is sown an animal body, it will rise a spiritual body." ${ }^{49}$

With little exaggeration, it may be said that, from the apostle Paul to Pope John Paul II, the history of resurrection debates is a two-thousand-year-old attempt at working out the oxymoron spiritual body. Among Christians, the fundamental issue never was whether resurrection would take place or whether, resurrected, we will indeed be ourselves. God promised it and will therefore make it happen. The conceptual difficulty was to envision bodily selfsameness and its relation to what it means to be ourselves. Will resurrected bodies be numerically identical to the corresponding terrestrial bodies? If yes, how? And, if not, what will their qualitative identity depend on?

These questions date from the very beginning of Christianity. Thus replied Paul to those who denied the resurrection:

But some man will say, How are the dead raised up? And with what body do they come? Thou fool, that which thou sowest is not quickened, except it die: and that which thou sowest, thou sowest not that body that shall be, but bare grain, it may chance of wheat, or of some other grain: but God giveth it a body as it hath pleased him, and to every seed his own body. [1 Cor. 15:35-38]

Here we encounter the crucial metaphor of the seed, which affirms the necessity and redeeming significance of death and immediately directs resurrection discourses toward issues of decay, fertility, developmental processes, continuity, and identity. To each kind of seed its own body. Then, Paul continues,

so also with the resurrection of the dead. It is sown in corruption; it is raised in incorruption. It is sown in dishonour, it is raised in glory;

1998], pp. 90-91). For a study of the numerical identity of terrestrial and resurrected bodies, see Francisco Segarra, De identitate corporis mortalis et corporis resurgentis (Madrid, 1929). Although apologetic in intent, it contains useful historical information.

49. Augustine, De civitate Dei [ The City of God against the Pagans], trans. William M. Green (Cambridge, Mass., 1972), bk. 22, chap. 21, p. 303; hereafter abbreviated $C$. 
it is sown in weakness, it is raised in power; it is sown a natural body, it is raised a spiritual body. [1 Cor. 15:42-44] $]^{50}$

The resurrection body will be a new body, imperishable, glorious, powerful, and spiritual. Yet it will be somehow identical to the terrestrial one.

Later exegesis endowed the body of the blessed with the qualities of impassibility, brightness, agility, and subtility. All resurrected bodies will be incorruptible; but only those of the blessed will be impassible, feeling no pain or discomfort. Brightness will be their proper "glory," and it will be proportionate to merit. ${ }^{51}$ Agility, the capacity of moving with total freedom and celerity, represents the opposite of the terrestrial body's weakness; it is consistent with the resurrected Christ's capacity to pass through material objects. Subtility expresses the peculiar spirituality of a body governed by the soul but incapable, in turn, to affect it.

At the same time, the resurrected body will be carnal. This also conforms to the palpable body of the risen Christ. In the Gospel of Luke, the Christ appears suddenly in the midst of his disciples. In response to their terrified reaction, he tells them, "Behold my hands and my feet, that it is I myself: handle me, and see; for a spirit hath not flesh and bones, as ye see me have" (Luke 24:39). As in the episode of Thomas's incredulity, the physical body is the sole source of certainty. Those who cannot believe on faith alone must perceive a carnal body through their senses. "Except I shall see in his hands the print of the nails," announced Thomas, "and put my finger into the print of the nails, and thrust my hand into his side, I will not believe" (John 20:25). Eight days later he placed his hand in Christ's side-and believed.

To the Corinthians, Paul spoke of the "resurrection of the dead." The locution changed in the context of anti-Christian polemics. Irenaeus and Tertullian, for example, emphasized the physical resurrection of the flesh; and the controversial background must have been at least partly responsible for the choice of the word flesh.52 The Apostles' Creed declares, "I believe in the resurrection of the flesh," and the belief thus formulated was reaffirmed by later professions of faith. In the fourth century, the Athanasian

50. "Natural body" (other English versions say "physical” or "animal”) and "spiritual body" (in the vulgate, corpus animale and corpus spiritale) translate soma psuchikon and soma pneumatikon.

51. Paul writes that the dead body will be "raised in glory" and "there is one glory of the sun, and another glory of the moon, and another glory of the stars: for one star differeth from another star in glory" (1 Cor. 15:41). Brightness also corresponds to the body of the transfigured Christ, whose "face did shine as the sun" and whose "raiment was white as the light" (Matthew 17:2; see also Mark 9:2-4, Luke 9:28-30).

52. See Gunnar af Hällstrom, Carnis resurrectio: The Interpretation of a Credal Formula (Helsinki, 1988). See also John Norman Davidson Kelly, Early Christian Creeds (London, 1950), p. 165. For the Church Fathers, see the anthology of their writings by Joanne E. McWilliam Dewart, Death and Resurrection (Wilmington, Del., 1986). 
Creed asserted that all men will be resurrected with their own bodies (omnes homines resurgere habent cum corporibus suis), and the Fides Damasi, that we will be resurrected in the same flesh in which we presently live (in hac carne, qua nunc vivimus)..$^{53}$

Today's Roman Catholic Church affirms the numerical identity of terrestrial and resurrected flesh. In 1981, Pope John Paul II explained that, in the afterlife, human beings will keep their psychosomatic nature and that the resurrection is a restoration "to the true life of human corporality." ${ }_{54}$ The 1992 Catechism of the Catholic Church ( $\$ \$ 988-1001$ ) calls for a realist understanding of the dogma. The previous great Catholic catechism, the Professio fidei tridentinae of 1564, incorporated the Nicene Creed of 381, which speaks of the resurrection of the dead. Cardinal Joseph Ratzinger, prefect of the Sacred Congregation for the Doctrine of the Faith, points out that the resurrection of the flesh signifies the resurrection of the "creature" (the created being) only if it also implies the resurrection of the body. ${ }^{55}$ Such assertions illustrate an anthropology that gives the body positive relevance; The person exists only in an embodied form; possession of the same flesh attests to possession of the same self. Such are the basic convictions highlighted by the doctrine of the resurrection. The problem is how to understand the notion of the same flesh and its relation to identity.

In the earliest times of Christianity, attacks against the new religion often aimed at the resurrection belief. When the Athenians heard Saint Paul preach it, "some mocked, and others said, We will hear thee again on this matter" (Acts 17:32). Pagan critics questioned its possibility and raised problems concerning the sameness of terrestrial and resurrected bodies. Circa 178, Celsus authored the first comprehensive polemic against Christianity and declared that, as a phenomenon, the resurrection of the dead was incomprehensible, that it would be contrary to God, and that the doctrine proved the lack of spirituality of the new faith. Arising from the dead with the self-same flesh "is simply the hope of worms." ${ }^{56} \mathrm{He}$ and others such as

53. For all professions of faith, see Heinrich Denzinger, Enchiridion Symbolorum: Definitionum et declarationum de rebus fidei et morum, ed. Adolf Schönmetzer, 32d ed. (Freiburg-im-Breisgau, 1963).

54. John Paul II, "Propos sur la résurrection" (1981), trans. René de Ceccaty, Le Temps de la réflexion 3 (1982): 93.

55. See Joseph Ratzinger, Eschatology, Death, and Eternal Life, trans. Michael Waldstein, ed. Aidan Nichols (Washington, D.C., 1988). On this point, as on others, Hans Küng, the suspended Catholic theologian, is a powerful dissident voice. In Eternal Life? he treats resurrection as a metaphor, as a way of saying the daily struggle against the "death" that affects humankind at the personal, intersubjective, and social levels. See Hans Küng, Eternal Life? Life after Death as a Medical, Philosophical, and Theological Problem, trans. Edward Quinn (London, 1984).

56. Origen, Contra Celsum [Against Celsus], trans. Henry Chadwick (Cambridge, 1953), bk. 5, $\$ 14$, p. 274. Celsus's anti-Christian polemic, Alethes logos (On the True Doctrine), is known only through Origen's quotations. 
Plotinus's disciple Porphyry in his treatise Against the Christians pointed out the difficulties of imagining how corpses will be recomposed. It was also asked how resurrected bodies might possibly include all their original substance. In turn, Christian thinkers pondered the age, gender, and anatomical makeup of the resurrected body and such questions as whether it would include sexual organs or all the matter cut out of nails and hair.

A good idea of the range of issues early Christian apologists had to tackle in response to critics' objections is given in the last book of Augustine's De civitate Dei, which deals with the eternal happiness of the blessed as ultimate end of the city of God (see $C$, bk. 22). First, why should we doubt that it is possible to "transfer" earthly bodies to a "heavenly home"? It is, after all, not a "more marvellous work of God" than joining the soul with the body (C, bk. 22, chap. 4, pp. 185, 189). Second, most nations already believe such incredible things as the Christ's resurrection and ascension to heaven; and is it not unbelievable that a few unskilled men were able to persuade them (see $C$, bk. 22, chap. 5)?

Platonist ratiocinatores think that the natural weight of the elements will prevent an earthly body from being in heaven. Yet, Augustine asked, shall we deny that God, who gave "lightness to the earthly bodies of birds," can make immortal human bodies "dwell even in the highest heaven" ( $C$, bk. 22, chap. 11, p. 259)? And cannot an artisan shape a piece of metal so that it will float instead of sink ${ }^{57}$ As for aborted fetuses, who lived and died in the womb, it is impossible to decide whether they will be resurrected (see $C$, bk. 22, chap. 13). Nevertheless, if they are among the dead, then there is no reason to deny it. A fortiori, infants who die after birth will resurrect. But what will be the form of their body? Not that in which they died. Rather, "by a miracle of God [they] will receive in a moment the form which would have accrued to them at a later time" so that the resurrected body conforms to its original design (ratio), that is, to what potentially existed in the seed (C, bk. 22, chap. 14, pp. 274-75).

What will resurrected bodies look like? Will they all have the same size as the Christ's? No, answers Augustine: "each one is to receive his own measure," but in a state of youth that corresponds to the age and strength Jesus reached before his death ( $C$, bk. 22, chap. 15, p. 277). As for women, their defects will disappear just as from all other bodies, and their sex will be preserved, for it "is not a defect, but a natural state." Since in heaven there will be no intercourse or childbirth, female parts will be suited for a "new beauty" that does not provoke lust, but inspires "praise of the wisdom and

57. Platonist arguments about the weight of bodies are discussed extensively in $C$, bk. 13, chap. 18. 
goodness of God" ( $C$, bk. 22, chap. 17, p. 281). Such preservation of organs is consistent with Jesus's words, "But there shall not an hair of your head perish" (Luke 21:18). Augustine realizes that, for hair as well as deformities, matter cannot be restored to its original location ( $C$, bk. 22, chap. 19). Resurrected bodies will therefore comprise all their terrestrial substance but distribute this substance differently, as when a statue is redone after having been melted down, or a pot's clay is reused to make a new pot. ${ }^{58}$ Martyrs' bodies will perhaps show the scars of their "glorious wounds," but these will be an honor, "and in their body will shine a certain beauty, not of body, but of virtue" ( $C$, bk. 22, chap. 19, p. 295).

However disintegrated and scattered, all bodies, even those devoured by beasts or cannibals, will be made whole (see $C$, bk. 22, chap. 20). In sum,

only let every deformity be excluded, every weakness, impediment or decay, and whatever else is not suited to a kingdom in which the sons of the resurrection and the promise will be equal to the angels of God-if not in body, or age, at least in happiness. [C, bk. 22, chap. 20, p. 301]

All this is to be cautiously asserted. The promise of resurrection and eternal life cannot be doubted. "But," concludes Augustine, "since we have had no experience as yet to tell us what this spiritual body is, or how great its beauty is, I suspect that all utterance published concerning it is rash" $(C, \mathrm{bk} .22$, chap. 21, p. 303).

The most puzzling difficulty concerned the substance of persons eaten by cannibals or by animals who were in turn eaten by humans. Some early Christian responses to this objection employed physiological arguments. In De resurrectione mortuorum (chaps. 5-8), the second-century Athenian apologist Athenagoras claimed that human flesh cannot assimilate human flesh. Two hundred years later, Augustine explained that, because all digested matter eventually dissipates into the air, God can easily retrieve it and return it to their original possessors (see $C$, bk. 22, chaps. 12, 20).

Although no new doubts about the resurrection were raised after the second century, Christian theologians kept examining the earlier ones and advancing new replies. In the process, bodily identity and continuity remained crucial, and replies to objections were consistently framed so as to preserve the numerical identity of matter.

In the thirteenth century, Thomas Aquinas adopted the Aristotelian view that soul is the "form" of a natural body that potentially has life. ${ }^{59}$ Soul and

58. See Augustine, The Enchiridion of Faith, Hope, and Love, trans. pub. (Washington, 1996), chap. 89 , pp. 103-4.

59. See Aristotle, De anima, 412a.20. 
body accomplish themselves only when joined to each other. This must be understood in relation to Aquinas's ontology. As he explained in De principiis naturae, in things that are numerically one, both the form and the matter are numerically one. But, following Aristotle, he considered that matter is only potentiality; this potential something deprived of actual being can become actuality through the form. Sperm (matter) is potentially a human being, but becomes this being through soul (form). In the case of a bronze statue, we have matter (the bronze that is potentially a statue), privation (the shapelessness of matter), and form (the shape by which we call it a statue). When applied to the issue of identity, this ontology reinforced the paradoxical nature of the resurrection doctrine.

At the moment of death, the soul departs from the body. The body disintegrates, and the corpse, according to Thomas, does not have a natural inclination to resurrect. At resurrection, its fragments rejoin the soul that originally animated them only by virtue of a providential law. Aquinas considers resurrected bodies as numerically identical to terrestrial bodies but implies that same matter is that which is animated by the same form. ${ }^{60}$ Ultimately, then, it is the sameness of soul-as-form that accounts for identity and spatiotemporal continuity. However, as form is not itself being but that by which something has being, it is impossible (except by conceptual abstraction) to separate body and soul; and this applies to resurrected bodies as much as to anything else. Thus, Aquinas's apparent spiritualization of identity did not entail a neglect of body. On the contrary, insofar as the essence of soul is to be the form of body, embodiment is by nature its proper condition. The resurrection of the body will therefore remove the contra naturam condition of separated souls. ${ }^{61}$ Accordingly, Aquinas dealt in detail with the same contentious issues as his predecessors (hair, nails, sexual organs, aborted fetuses, cannibalism). As he wrote, "the soul ... is not the whole man, and my soul is not I." 62 The resurrected body will be a transformed body; it will be glorious and spiritual, but it will also be the same as a terrestrial body and just as material.

\section{Resurrection and Natural Philosophy}

The solutions of the Church Fathers and other medieval theologians did not placate the trouble produced by pagan objections, and each generation

60. See Aquinas, Summa theologica, suppl. QQ. 78, art. 3, 5:2876-77; and QQ. 79, art. 1-2, 5:2877-81.

61. See Anton C. Pegis, "The Separated Soul and Its Nature in St. Thomas," in Saint Thomas Aquinas, 1274-1974: Commemorative Studies, ed. Armand Maurer et al., 2 vols. (Toronto, 1974), 1:131-58.

62. "Anima... non est totus homo, et anima mea non est ego" (Aquinas, "Super primam epistolam ad Corinthios lectura," in Super epistolas S. Pauli lectura, ed. Raphael Cai, 2 vols. [Torino/Rome, 1953], 1:411, chap. 15, lect. 2, no. 924). 
looked for new solutions. In the Early Modern period, however, resurrection discourses became increasingly differentiated. Poetry and the visual arts emphasized the most carnal aspects; theology expounded the doctrine; and alchemists and natural philosophers tried to explain the processes whereby resurrection might take place.

In presenting the creed, the Catechism of Trent pointed out that, in contrast to other articles, the resurrection of the body is not only proposed by the Scriptures "to the belief of the faithful, but is also confirmed by numerous arguments," and it admitted that "analogies from nature" are useful to show that the doctrine does not contradict nature or human reason. ${ }^{63}$ As stated by a seventeenth-century archbishop of Canterbury, "the resurrection is not a thing incredible to natural reason." ${ }^{64}$ But for him, as for all earlier and later Christian thinkers, faith remained the sole foundation; and theology's mission was to assert the doctrine's truth. The Reformer John Calvin did so in several places of his work; in his 1544 Brieve instruction against the Anabaptists, he defended its ultimate basis, the humanity of Christ. In the third book of Jean Bodin's Colloquium heptaplomeres (written 1588), an extended dialogue on the "secrets of the sublime" between a skeptic, a philosophical naturalist, a Jew, a Muslim, a Catholic, a Calvinist, and a Lutheran, the Christians assert their belief in the resurrection of the flesh but do not seek to oppose physical arguments to the naturalist's objections. ${ }^{65}$ John Milton, whose rejection of the Trinity and the immortality of the soul made him look heretical in the context of the Restoration, was absolutely certain "that every man will rise numerically one and the same person." ${ }^{66}$ None of these very different authors dealt with naturalistic objections. Neither did John Bunyan, the mystical and didactic author of Pilgrim's Progress, though he likened the formation of the resurrected body to the apothecary's candying of a sour substance that nevertheless "doth still retain its own proper Nature and Essence." ${ }^{67}$

Outside strictly theological discourse, however, naturalistic arguments were prominent. Used since Athenagoras in the second century to respond

63. Catechismus Romanus [Catechism of the Council of Trent for Parish Priests], trans. John A.

McHugh and Charles Callan (Rockford, Ill., 1982), pt. 1, art. 11, pp. 120, 122.

64. John Tillotson, “The Possibility of the Resurrection Asserted and Proved” (1682), The Works of Dr. John Tillotson (London, 1820), 8:339.

65. See Jean Bodin, Colloquium of the Seven about Secrets of the Sublime, trans. Marion Leathers Daniels Kuntz (Princeton, N.J., 1975), bk. 3.

66. Milton, De doctrina christiana (ca. 1658-65), ed. Frank Allen Patterson et al., vol. 16 of The Works of John Milton, trans. Charles R. Sumner, ed. James Holly Hanford and Waldo Hilary Dunn (New York, 1934), p. 353.

67. John Bunyan, The Resurrection of the Dead (1665), ed. J. Sears McGee, vol. 3 of The Miscellaneous Works of John Bunyan, ed. Roger Shattuck (Oxford, 1987), p. 224. 
to the food chain objection, they are the core of alchemical reasoning. Alchemists found that the ashes of certain plants become the germs of new plants; resurrection thus became an instance of "palingenesis," the new birth or resuscitation of a disintegrated mineral, vegetal, or animal body. ${ }^{68}$ In such a context, explanations of Paracelsian inspiration mingled with the soteriological sense of alchemical symbolism. ${ }^{69}$ Mercury, for example, after its reduction to dust or mixture with other substances, can recover its initial integrity and purity thanks to mechanical actions or by being heated in a special vase. Emblems of the resurrection evoke these operations when they depict a vase accompanied by the legend Redivivus a pulvere or Redivivus $a b u r n a .{ }^{70}$ In a universe organized by correspondences of microcosm and macrocosm and filled with "signatures," emblems such as those related to mercury exhibited the natural mechanisms whereby resurrection could take place. ${ }^{71}$ Both literally and figuratively, alchemical manipulations for reconstituting substances were physical models for the resurrection. That, precisely, is what motivated a seventeenth-century Jesuit's bitter reproach that, for alchemists, the resurrection was as natural as the birth of a chicken in the furnaces of Egypt. ${ }^{72}$

68. See Jacques Marx, “Alchimie et palingénésie,” Isis 62 (Sept. 1971): 275-89. On how palingenesis experiments fit in the epistemological and argumentative framework of atomism (and for further references), see Christoph Meinel, "Early Seventeenth-Century Atomism: Theory, Epistemology, and the Insufficiency of Experiment," Isis 79 (Mar. 1988): 68-103; see esp. pp. $78-81$.

69. Soteriology, from the Greek soterion, "salvation," is the branch of theology that deals with salvation (especially through Christ). The soteriological dimension of alchemy is not directly aimed at a physico-theology of resurrection. In the thirteenth century, the Oxford Franciscan Roger Bacon looked for ways to give the body incorruptibility and prolonged youth through alchemy, not for youth's sake, but to prepare it for resurrection and eternal life. The chief means was the consumption of drinkable gold, the incorruptible matter par excellence and a symbol of the equilibrium of the microcosm; see Agostino Paravicini Bagliani, "Storia della scienza e storia della mentalità: Ruggero Bacone, Bonifacio VIII e la teoria della 'prolongatio vitae," in Aspetti della letteratura latina nel secolo XIII, ed. Claudio Leonardi and Giovanni Orlandi (Spoleto, 1992), pp. 243-80. After the Reformation, alchemy became entangled with apocalyptic expectations. Its success during the seventeenth century is linked to the perception that it carried "the secret of life itself, and with it the secrets of resurrection, of immortality, of perfection, of final salvation and Beatitude" (Betty Jo Teeter Dobbs, "Alchemical Death and Resurrection: The Significance of Alchemy in the Age of Newton," in Science, Pseudo-science, and Utopianism in Early Modern Thought, ed. Stephen A. McKnight [Columbia, 1992], p. 87).

70. For the emblematics of resurrection, see Filippo Picinelli, Mundus symbolicus, in emblematum universitate formatus, explicatus, et tam sacris, quam profanis eruditionibus ac sententiis illustratus (1669), facs. 1694 ed., trans. August Erath, 2 vols., Index applicationum (New York, 1976), s.v. "Resurrectio mortuorum."

71. Signatures are analogical signs of the essence, purpose, and use of things (a yellow flower is good for jaundice, the powder of a rhinoceros's horn, effective as a male aphrodisiac).

72. See François Garasse, La Doctrine curieuse des beaux esprits de ce temps, ou pretendus tels, contenant plusieurs maximes pernicieuses à la religion, à l'estat, et aux bonnes moeurs (Paris, 1623), p. 296. The Egyptians were supposed to use furnaces as incubators and thus to be able to produce cheaply a vast number of chicks. The process was examined in some detail by the anatomist 


\section{Resurrection and the "New Philosophy"}

The physico-theology of resurrection appears to have changed radically during the seventeenth century in connection with the critique of Aristotelianism and with the corpuscular and mechanistic conception of nature. On the one hand, embryology became the model for resurrection mechanisms and called into question the notion of life as a product of death. On the other hand, the visible properties of bodies were no longer accidents, manifestations of an underlying substance that functioned as a neutral substratum characterized by potentiality. Rather, they were the result of the number, motion, and position of particles that were the same for all bodies. It is in this context that the question of what constitutes sameness at different times took precedence over the traditional question of individuation (what produces individuality)..$^{73}$

Seventeenth-century natural corpuscularism strengthened earlier beliefs in the universal transmutability of substances. To the extent that things do not differ in their ultimate material components, they can be, in principle, transformed into anything else. The atomistic foundation of transmutability was deemed incompatible with the eucharistic doctrine of the Roman Catholic Church. ${ }^{74}$ Against various Protestant interpretations, the Council of Trent affirmed the Christ's "real presence"; that is, in the eucharist, Jesus Christ is "truly, really, and substantially" contained in the consecrated bread and wine. ${ }^{75}$ Real presence resulted from transubstantiation-transformation of the whole substance of the consecrated species into the substance of Christ's body. But it did not change the external appearance of the bread and the wine. The corpuscularian philosophy, however, implied that a modification of the mechanical dispositions of a body's composing particles produces outward transformations. The problem for the resurrection of the body is the converse. In the eucharist as defined in Roman Catholicism,

Johann Vesling; see Johann Vesling, "Observationes philosophicae \& medicae de pullorum in Aegypto exclusione mediante calore elementari," Joannis Veslingi mindani equitis observationes anatomica \& epistolae medicae ex schedis posthumis, ed. Thomas Bartholin (1664; The Hague, 1740), chap. 1. On the period, see Marie-Madeleine Fragonard, "De la résurrection des morts, et de sa justification rationnelle à la fin du XVIe siècle," in L'Imaginaire du changement en France au XVIe siècle, ed. Claude-Gilbert Dubois (Bordeaux, 1984), pp. 79-100.

73. See Udo Thiel, "Individuation," in The Cambridge History of Seventeenth-Century

Philosophy, ed. Daniel Garber and Michael Ayers, 2 vols. (New York, 1998), 1:212-64.

74. Eucharist, is from the Greek eucharistos, "grateful," and eucharistia, "thanksgiving." The eucharist or communion is a Christian sacrament in which consecrated bread and wine (also called species in Roman Catholicism) are consumed as a memorial of Christ's death. It is based on the Last Supper taken together by Jesus and the apostles; see Matt. 26:26-28; see also John 22:17-20.

75. Council of Trent, Canons and Decrees of the Council of Trent, ed. H. J. Schroeder (1551; London, 1971), session 13, canon I, and "Decree Concerning the Most Holy Sacrament of the Eucharist," chap. 1, p. 73. 
appearance is maintained while the underlying substance becomes totally other. In resurrection, the body is radically transformed, but its numerical identity is maintained. In the case of the eucharist, the corpuscular philosophy questioned change; in the case of the resurrection, it questioned permanence. ${ }^{76}$ As a consequence, it drastically limited the role of numerical sameness. It did this in two basic frameworks, the psychological and the physico-theological, which combined with each other as well as with embryological and neurological considerations.

\section{The Psychological Framework}

In the chapter "Of Identity and Diversity" added to the second edition of the Essay Concerning Human Understanding (1694), John Locke set forth what is arguably one of his fundamental philosophical innovations: the separation between substance and personal identity. ${ }^{77}$ The theory starts with the distinction between man and person. The identity of the man consists in "a participation of the same continued Life ... in succession vitally united to the same organized body"; nobody, Locke commented, "could he be sure that the soul of Heliogabalus were in one of his hogs, would yet say that hog were a Man or Heliogabalus" (EC, $\$ 6$, p. 332). In contrast, the person is defined as "a thinking intelligent Being, that has reason and reflection, and can consider it self as it self, the same thinking thing, in different times and places" ( $E C, \$ 9, \mathrm{p} .335$ ). Personal identity, therefore, resides in a continuity of memory and consciousness, in "the sameness of a rational Being: and as far as this consciousness can be extended backwards to any past Action or thought, so far reaches the identity of that person" (EC, \$ 9, p. 335). Personal identity depends exclusively on the "same consciousness that makes a Man be himself to himself," regardless of the substances to which consciousness is "annexed" ( $E C, \S 10, \mathrm{p} .336)$. It follows that self (which is for Locke that which the word person names [see EC, $\$ 26, \mathrm{pp} .346-47$ ]) also depends on consciousness and not substance. Thus, if my little finger is severed from my hand and my consciousness happens to stay with it, "'tis evident the

\footnotetext{
76. As noted by the Jansenist theologian Antoine Arnauld, the accusation that atomism undermined the doctrine of the resurrected body was rarely formulated. In part three of his Examen du traité de l'essence du corps contre Descartes, written in 1680, he argued (against the claim that glorious bodies could not be extended, but must be confined to an indivisible mathematical point) that the Cartesian notion of matter was not incompatible with the materiality and qualities of the glorious body. See Antoine Arnauld, Examen du traité de l'essence du corps contre Descartes, ed. Emmanuel Faye (Paris, 1999).

77. John Locke, An Essay Concerning Human Understanding, ed. Peter H. Nidditch (Clarendon, 1979); hereafter abbreviated EC; unless otherwise indicated, all references are drawn from bk. 2, chap. 27.
} 
little finger would be the Person, the same Person; and self then would have nothing to do with the rest of the Body" (EC, $\$ 17$. p. 341).

At resurrection, it is of course the person that counts. Indeed, memory is crucial for judgment and imputation. Sentences passed on Judgment Day will be justified by the consciousness resurrected persons will have of being the same as those who committed the actions for which they are rewarded or punished; and this will be so, Locke declared, "in what Bodies soever" the resurrected appear. Being rewarded or punished in the absence of such consciousness would amount to the injustice of being created happy or miserable, "without any demerit at all" ( $E C, \$ 26$, p. 347). In Locke's view, difficulties with the resurrection doctrine are solved by the distinction between man and person and by the identification of self with the latter. For while body and soul together make the man (and controversies are related to the body), it becomes possible, thanks to the new theory, "without any difficulty to conceive, the same Person at the resurrection, though in a Body not exactly in make or parts the same which he had here" (EC, $\$ 15, \mathrm{p}$. 340). Locke drew the corollary of such considerations in his theological commentaries, where he emphasized that "those who are raised to an heavenly state shall have other bodies." 78 As he wrote in a letter, "I being fully perswaded of the resurrection and that we shall have bodys fitted to that state it is indifferent to me whether any one concludes that they shall be the same or not."79

In sum, Locke's solution consisted of redefining the terms of the question and of emptying the self from the body and the body from the self. The sameness (idem) of terrestrial and resurrected bodies ceased to be a criterion for determining the identity (ipse) of resurrected persons. In the words of Paul Ricoeur, Locke's conception marks a turning point in which "ipsity" replaces sameness. ${ }^{80}$ From then on, personal identity would be based almost exclusively on psychological properties. It was immediately realized that Locke's theory threatened the received dogma of the resurrection of numerically same bodies. ${ }^{81}$ The Lockean reduction of the anthropological

78. Locke, A Paraphrase and Notes on the Epistles of St. Paul to the Galatians, 1 and 2 Corinthians, Romans, Ephesians (1707), ed. Arthur W. Wainwright (Oxford, 1987), p. 252n.

79. Letter to D. Whitby, 17 Jan. 1698-99, quoted in Maria-Cristina Pitassi, "Une Résurrection pour quel corps et pour quelle humanité? La Réponse lockienne entre philosophie, exégèse, et théologie," Rivista di storia della filosofia, no. 1 (Summer 1998): 61.

80. "Le tournant de la réflexion et de la mémoire marquait en fait un renversement conceptuel où l'ipséité se substituait silencieusement à la mêmeté" (Paul Ricoeur, Soi-même comme un autre [Paris, 1990], p. 151).

81. Sketches of the debates are given in John W. Yolton, A Locke Dictionary (Oxford, 1993), pp. 233-37, and Locke: An Introduction, ed. Yolton (Oxford, 1985), pp. 97-98. For fuller treatments, see Alan P. F. Sell, John Locke and the Eighteenth-Century Divines (Cardiff, 1997), pp. 250-62, and Thiel, "Personal Identity," in The Cambridge History of Seventeenth-Century Philosophy. The matter is also treated in Philip C. Almond, Heaven and Hell in Enlightenment England, who wrongly states that, for Locke, "the resurrection of the flesh was not necessary" (Philip C. Almond, 
problem of identity to the legal and moral concept of person seems to have been rarely understood by early theological controversialists (and was, in any case, rejected); but a number of naturalists who accepted it did not give up the body entirely when pondering the resurrection. Locke's severing of self from questions of numerical material identity thus converged with the physico-theological consequences of the corpuscularian and mechanical philosophy.

\section{The Physico-theological Framework}

The defense of the corpuscularian and mechanistic theory of matter, in opposition to Aristotelian hylomorphism and the explanation of natural phenomena by forms and qualities, runs through the work of Robert Boyle. Like Newton and other figures of the "new philosophy," Boyle did not keep mechanics, alchemy, and religion strictly separate. Particularly relevant for us are his attempts at demonstrating the existence of primary particles as the ultimate components of matter by showing that certain properties of substances can persist through chemical and physical transformations. Thus, he interpreted the "redintegration of salt-petre" (of which he wrote in Certain Physiological Essays of 1661) in terms of the mechanical modifications of particles that do not differ qualitatively from one substance to another. Substances, and therefore bodies, differ as a result of variations in the number, position, and motion of the composing particles. He often cited, and claimed to have replicated, Jan Baptista van Helmont's experiment. Plant a young tree in a previously weighted amount of earth; water it carefully; let it grow; then control the weight of the earth. You will notice that it has barely diminished. Conclusion: the water has been transformed into wood. For Boyle, this observation confirmed that all bodies are made of a uniform matter and validated the universal transmutability of substances:

I would not say, that any thing can immediately be made of every thing ... yet since bodies, having but one common matter, can be differenced but by accidents, which seem all of them to be the effects and consequents of local motion, I see not, why it should be absurd to think that ... by the intervention of some very small addition or sub-

Heaven and Hell in Enlightenment England [Cambridge, 1994], p. 141; see also pp. 131-43). Directly relevant to the issues discussed here are Etienne Balibar, John Locke: Identité et différence: L'Invention de la conscience (Paris, 1998); Edwin McCann, "Locke's Philosophy of Body," in The Cambridge Companion to Locke, ed. Vere Chappell (New York, 1994), pp. 56-88; Nicholas Jolley, Leibniz and Locke: A Study of the New Essays on Human Understanding (Oxford, 1984), chap. 7; and Raymond Martin, "Locke's Psychology of Personal Identity," Journal of the History of Philosophy 38 (Jan. 2000): 41-61. 
traction of matter ... and of an orderly series of alterations ... almost of any thing, may at length be made any thing. ${ }^{82}$

What such certainties meant for the physical conditions of the resurrection will be immediately apparent.

As for Locke, the resurrection of the dead was for Boyle "above reason." ${ }^{83}$ This meant only that its truth or probability can be established neither by deduction nor by tracing our idea of it from sensation and reflexion. Resurrection will result from divine intervention; that it will take place is not probable but absolutely certain. Nevertheless, because it cannot be contrary to reason or the laws of nature its rank as a mystery of Christian faith does not preclude examining its natural feasibility. This is precisely what Boyle does in "Some Physico-theological Considerations about the Possibility of the Resurrection" (1675)..$^{84}$

Boyle begins by arguing for a notion of identity he characterizes as more flexible than the then-current one and closer to that of early Christianity. Indeed, because during our lifetimes we lose and renew most of our bodily substance, why demand that the totality of the original matter be restored at resurrection? A classical alchemical observation supported the argument. Burn a poppy and plant its ashes; a new plant will arise. This shows that a "plastick," form-giving power remains in the "fixed," nonvolatile particles of the plant. Boyle thinks that accounting for the physical possibility of the resurrection does not even require such a power. The original creation of man suffices to demonstrate God's ability to make bodies. In addition, Ezekiel's vision (fig. 1) shows "that a portion of the matter of a dead body, being united with a far greater portion of matter furnished from without by God himself, and completed into a human body, may be reputed the same man, that was dead before" ("S," p. 195). ${ }^{85}$ The continuity of the resurrected and

82. Quoted in Richard S. Westfall, The Construction of Modern Science: Mechanism and Mechanics (New York, 1977), pp. 77-78.

83. Some things, Locke explained in the Essay Concerning Human Understanding, are "according to Reason" (propositions whose truth can be established by deduction or by tracing ideas formed by sensation and reflexion, such as the existence of God); others are "above Reason" (propositions whose truth or probability cannot be established in the same way, such as the resurrection of the dead); and yet others are "contrary to Reason" (propositions inconsistent or irreconcilable with "our clear and distinct Ideas," such as the existence of more than one God) (EC, bk. 4, chap. 17, $\$ 23$, p. 687).

84. Robert Boyle, "Some Physico-theological Considerations about the Possibility of the Resurrection" (1675), The Works of the Honourable Robert Boyle, 2d ed. (London, 1772), vol. 4; hereafter abbreviated "S."

85. The "hand of the Lord" takes Ezekiel to a valley of dry bones. God orders him to prophesy that the bones shall be covered with sinews, flesh, and skin, and will live. As he prophesied, there was a noise and a shaking, and the bones came together. Then God breathed upon them, "and they lived, and stood up upon their feet, an exceeding great army" (Ez. 37:1-11). Although in Ezekiel the scene is said to symbolize the fate of the "house of Israel," Christians saw in it an announcement and confirmation of the resurrection of the dead. 

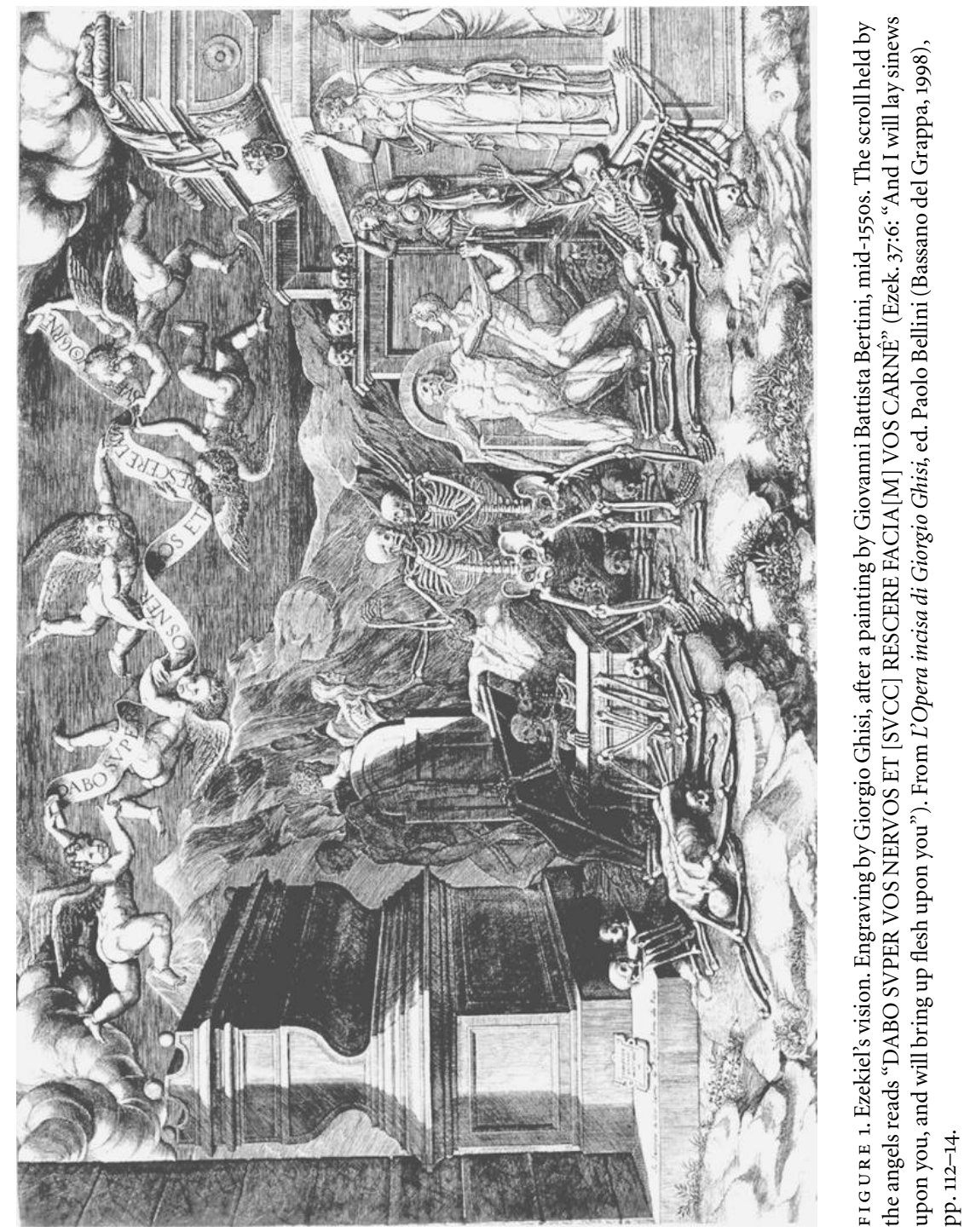

This content downloaded from 158.109.210.195 on March 02, 2016 04:50:12 AM

All use subject to University of Chicago Press Terms and Conditions (http://www.journals.uchicago.edu/t-and-c). 
the terrestrial person, therefore, does not necessitate the numerical identity of physical bodies.

Similar considerations allow Boyle to reply to the traditional objections. A body may contain corpuscles that belonged to another body without, for that reason, losing its properties. This is evident from operations with gold and mercury and by analogous phenomena from the plant and animal world (butter can taste like the herbs eaten by the cows that furnish the milk; some marine birds have a fishy flavor). Moreover, the body is in "perpetual flux," and only bones are durable. There is therefore "no determinate bulk or size, that is necessary to make a human body pass for the same" ("S," p. 196). In conclusion, differences among physical bodies do not derive from the nature of their substance but from the mechanical properties of the qualitatively identical particles that compose them. It is possible to modify these properties so as to return a body to an earlier state, and that is what God will do with our corpses at the end of time. God, indeed, can do everything and anything with the principles of matter and motion. "And that his power extends to the re-union of a soul and body, we may learn from the experiments God has been pleased to give of it in the Old Testament and the New, especially in the raising again to life Lazarus and Christ" " $S$," p. 200).

The glorious body will be made of true flesh, but the disposition of its particles will give rise to new qualities, the four traditional dotes corporis gloriosi. Again, this is the work of God, who can endow bodies with such extraordinary features by temporarily suspending the usual course of nature. Several biblical episodes provide Boyle with appropriate models. God made an iron axe come afloat from the river Jordan (2 Kings 6:1-7); and He protected Daniel's companions in Nebuchadnezzar's furnace (Dan. 3). On those occasions, God cancelled the "native gravity" of the iron and the action of the flame ("S," p. 201).

In less miraculous terms, the conversion of terrestrial bodies into glorious bodies is understood by analogy to chemical transformations. Boyle seems delighted to report that he manufactured transparent, finely colored glass out of dark, opaque lead. Finally, he notes rather poetically, we can light a candle that has just been put off by approaching a flame to its stillsmoking wick. This is for him a good image for the manner in which the glorious body will arise. "For, in the twinkling of an eye, an opacous, dark, languid and stinking smoke loses all its stink, and is changed into a most active penetrant and shining body" (“S," p. 202).

The gist of Boyle's argument is that since no one particular portion of matter determines personal identity, the sameness of the terrestrial and the resurrected individual is not to be judged by material criteria. The soul, in 
his view, "shall be again united, not to an aetherial, or the like fluid matter, but to such a substance as may, with tolerable propriety of speech ... be called a human body" (“S," p. 201). The basic, minimal substance must be nonvolatile and possess plastic power. In a similar argument, and also citing resurrected plants, Leibniz speculated that each body possesses a "flower of substance" endowed with a "seminal power." ${ }^{86}$ The conservation of such "flower" could account for the physical possibility of resurrection. Again, numerical identity is no longer the ultimate criterion for individualidentity, nor for the identity between terrestrial and resurrected bodies.

\section{Physiology and Neuropsychology of Resurrection}

Physico-theology and psychology converged toward the disembodiment of self; but neither alchemical nor mechanical models could determine the "portion of the matter of a dead body" necessary for resurrection. The task of doing so belonged to the life sciences. Two approaches emerged in the context of resurrection debates. One tried to identify the minimal, sine qua non structures of living bodies; another aimed at discovering developmental principles responsible for the formation of resurrected bodies. But I should first illustrate an alternative to the approaches of corpuscularian mechanism and solidist physiology - a theory that, though partially combined with them, emphasized the role of fluids and saw nature as both animated by vital and psychical forces and as irreducible to matter in motion.

In A Treatise Concerning the State of Departed Souls, the Scottish jurist and theologian Thomas Burnet, best known for his Sacred Theory of the Earth (1681), considered that resurrected bodies will be like those of angels and that anatomical questions are therefore irrelevant. ${ }^{87}$ The whole debate on numerical identity seemed to him "rather curious than necessary." "How can it concern us," he wondered, "what becomes of our Leavings, and Carkasses, provided we live in the Light of Heaven, and in the Society of Angels?” (T, p. 232). Obviously, God can again fashion our bodies with the original particles. It would be, Burnet wrote, "the most astonishing of all Miracles. But of such a Miracle, so manifold, and so useless, we have

86. In (al)chemical terminology, "flower" ( flos) designates the substance obtained by "sublimation" (that is, volatilization) and consisting of very fine particles; see Gottfried Wilhelm Leibniz, Examen religionis christianae [Systema theologicum] (1686?), in vol. 4, pt. C, Sämtliche Schriften und Briefe, ser. 6 [Philosophische Schriften] (Berlin, 1999), no. 420, p. 2453; and "De resurrectione corporum," appendix to "Leibniz für Herzog Johann Friedrich: De Usu et necessitate Demonstrationum Immortalitatis Animae" (1671), in ibid., ser. 2 [Philosophischer Briefwechsel], vol. 1 (Berlin, 1987), no. 59, pp. 115-17.

87. Thomas Burnet, A Treatise Concerning the State of the Departed Souls, Before, and At, and After, the Resurrection (1723), trans. "Mr. Dennis," 2d ed. (London, 1739); hereafter abbreviated T. 
hitherto had no Example. Thus much [he concluded] concerning the Insignificance and the Impertinence of the Thing" ( $T$, p. 243).

Still, Burnet did not shy from examining the resurrected body's special features. That it will be celestial yet material means that it will be, like Christ's, composed of a matter "as pure and thin, as the finest Air or Æther" (T, p. 209). As spiritual matter, it will be made of "spirits," extremely tenuous fluids, thanks to which it will conserve itself "without Meat, or Drink, or Sleep" (T, p. 209-10). As for its agility, it "does not proceed from the hard Body, but from some other subtle Matter in Motion inclos'd in the hard Body" (T, p. 210). The resurrected body will therefore be "spirituous" (thus were called in chemistry the most volatile and light substances) _ "nothing but a Frame of congregated Spirits and of the noblest Matter" (T, p. 212). Finally, it will be "glorious" because of a celestial light inherent in it, as in the face of the transfigured Christ ( $T$, p. 214). Burnet's view of the resurrected body is closer to a pneumatology (theory of disembodied spirits) than to a physiology; but this pneumatology itself is the physiology of a body composed of a "spirituous" substance.

\section{One's "Own Body"}

At the end of the seventeenth century, the English divine Humphrey Hody, who became Regius professor of Greek at Oxford, produced an entire treatise (against Locke) in defense of the doctrine of the resurrection of the same body. ${ }^{88}$ Hody agreed with Boyle that sameness of body did not depend on the numerical sameness of each and every particle but tried to specify the selfsame particles an individual glorious body must share with the corresponding terrestrial one. "T'is enough," he remarked, "that such Particles are rais'd as made up the integrant and necessary Parts of the Body" $(R$, pp. 187-88). The key notion is that of necessary parts. ${ }^{89}$ Hody defined them as "those which remain after the utmost degree of Maceration, without which the Body would not be Integral, but Imperfect." What were they? Bones, skin, nerves, tendons, ligaments, "and the Substance of the several Vessels." As long as these remain, he assured, "the body is truly Whole"; flesh added to them makes no difference to its integrality. Hody could thus solve the ancient cannibalism objection: the necessary parts "are not so apt for Nourishment" (R, p. 188).

As far as identity is concerned, Hody was categorical: "We cannot be Men

88. Humphry Hody, The Resurrection of the (Same) Body Asserted, from the Traditions of the Heathens, the Ancient Jews, and the Primitive Church (London, 1694); hereafter abbreviated $R$.

89. Also: "The Identity of the Rising Body, or its sameness with that which died, can consist in nothing else but in the Restauration of the same Particles of Matter, which made up the necessary Parts of the dying Body, to their former Construction" (R, p. 192). 
unless we have Humane Bodies." His refusal to follow Locke's distinction between man and person is absolute. He declared,

we cannot be the same Men unless we have the same Bodies. T'is a great Mistake to imagine that the Identity or Sameness of a Man consists wholly in the sameness of the Soul. If Euphorbus, and Homer, and Ennius, had had one and the same Soul, yet they would not have been one and the same, but Three distinct Men. [R, p. 218]

Three bodies animated by the same soul remain distinct-not merely as bodies but as full persons. Hody's position is as radically different from Locke's as from the identification of our selves to the contents of the brain.

Bodies, therefore, were considered integral to persons. Yet, given the changes bodies undergo during a lifetime, what constitutes a person's own body? The question was examined in those very terms in the chapter on the "possibility of resurrection" of The Religious Philosopher, a major natural theology by the Dutch naturalist, philosopher, and mathematician Bernard Nieuwentijt. ${ }^{90}$

To the difficult question about how bodies might be formed out of scattered particles, Nieuwentijt replied with an optical analogy. If the atoms of light can be subjected to certain natural laws to form a shadow, it should not be impossible for the same process to take place with the particles of dead bodies. Chemistry furnished an answer to objections from the destructibility of matter. Like Boyle, Nieuwentijt recalled that the properties of a given substance persist through mixtures and transformations and that the original substance can be retrieved thanks to chemical manipulations. In the makeup of the body, flesh, bones, and membranes are not confounded, and each is nourished by appropriate substances. Finally, distance between a corpse's particles is not a problem because the magnet attracts iron, and the universe is governed by the Newtonian law of attraction.

Nieuwentijt's goal was not so much to reply to traditional objections as to imagine a positive hypothesis about the possibility of resurrection. After all, "a bare Hypothesis is sufficient to shew the Possibility of Any Thing" $(R P, 3: 1049)$. He thus distinguished between "visible" body (also termed "peculiar" or "particular" body) and "proper" or "own" body. Although a person's visible body changes considerably in a lifetime, we recognize it as being that same person's body. This sameness is accounted for by the own body, which is invariable and belongs to one person alone: "if one says, that such a man is 80 Years old, it can only be meant of the own Body, since all the Food that he has used in the last 10, 20, or 30 Years of his Life cannot be

\footnotetext{
90. See Bernard Nieuwentijt, The Religious Philosopher, or the Right Use of Contemplating the Works of the Creator (1714), trans. J. Chamberlayne, 3 vols. (London, 1718), vol. 3, contemplation 28; hereafter abbreviated $R P$.
} 
said to have appertained to his visible Body the whole Space of 80 Years" $(R P, 3: 1050-51)$.

The visible body consists of fluids and solids and is governed by particular laws. But what is the own body? It cannot be fluids because they vary considerably and can even leave the body entirely. It cannot be physiological laws either, for different laws apply to women and men, the ill and the healthy, the old and the young; moreover, we do not hesitate to speak of an own body in relation to a corpse, which is no longer governed by the laws of living bodies. The own body, Nieuwentijt concludes, is therefore to be sought in "the simple and naked solid Parts thereof" and especially in the "stamen" of the body ( $R P, 3: 1053)$.

The "stamen" is the organic germ out of which the body develops. "It is very well known," writes Nieuwentijt, "to those that are versed in the Inquiries of the present Age," that plants, animals, and humans "consist of a first Principle or Stamen, which may therefore be denominated the own Body" ( $R P, 3: 1054)$. Nieuwentijt does not mention authors but makes clear his reference to contemporary embryology and, in particular, to the observations on the formation of the chick in the egg that Marcello Malpighi had reported to the Royal Society in 1672. In Malphighi's vocabulary, the latin word stamen (filament, thread) designated the earliest detectable traces of the embryo. The filaments were supposed to be preformed within the egg and to constitute the rudiments of the entire mature organism (figs. 2a and 2b)..$^{91}$

During organic growth, Nieuwentijt explains, the stamen either "unfolds" or is "cloathed," "filled," and "stuffed" with matter; whatever the theory, to the extent that the stamen contains all the solid parts of the body, it "must be reckon'd the own Body" ( $R P, 3: 1054)$. The own body is nothing other than "a Stamen increased to a certain Bigness" (RP, 3:1062); and a person's resurrected body need be nothing other than that same person's own body..$^{92}$ In sum, persons will resurrect with their own bodies by virtue of the stamen. The resulting body will truly be their own, whether or not the matter surrounding the stamen is numerically the same as that of the original terrestrial body:

there will be nothing more required, that such a Person should rise with his own Body, than that only this Stamen, separately from the

91. Marcello Malpighi, Dissertatio epistolica de formatione pulli in ovo [On the Formation of the Chick in the Egg], vol. 2 of Howard B. Adelmann, Marcello Malpighi and the Evolution of Embyrology (Ithaca, N.Y., 1966). On the concept of stamen, see ibid, 2:936-38, n. 3. For Nieuwentijt on the stamen, see The Religious Philosopher, contemplation 16.

92. This interpretation is reproduced in the vast anthropological encyclopedia of the Spanish Jesuit Lorenzo Hervás y Panduro, "Dificultades que se oponen á la resurreccion de los cuerpos," Historia de la vida del hombre, 7 vols. (Madrid, 1799), 7: 375-92. 


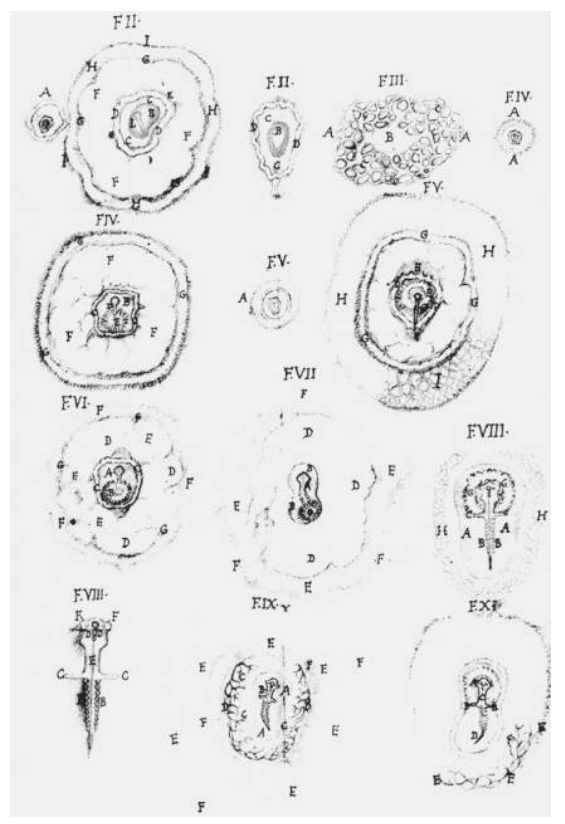

F I G U R E 2a. Figure 2a from Marcello Malpighi, Dissertatio epistolica de formatione pulli in ovo (1672). Malpighi's drawing of the "cicatricula" of a one-day old, not yet incubated egg, containing the preformed "first filaments" (stamina) of the chick. In the center there is a "cinereus saccule" or "follicle" (B) floating in a "colliquament" (C) that resembles molten glass and is surrounded by circles of solid (D, F, H) and fluid (E, G, I) matter. The fetus (L), wrote Malpighi, is enclosed in the saccule "as if in an amnion; and its head, with the stamina of the carina [first rudiments of the spinal cord] appended to it, was clearly evident." From: Howard B. Adelmann, Marcello Malpighi and the Evolution of Embyrology (Ithaca, N.Y., 1966).

Particles that cloath and fill the Body, should remain ... and that the great Author of our Resurrection should, after Death, unfold, fill and cloath the same into a visible Body, with the same Matter that belonged to it before ... or else with such other Matter as he shall be pleased to use. [RP, 3:1055]

Boyle had spoken of the "portion of the matter of a dead body" that, united by God with more matter to form a human body, will be reputed "the same man." The stamen turns out to be such portion of matter.

Thus Nieuwentijt was able (like Hody, but with more physiological precision) to formulate a decisive argument against the objection from anthropophagy ${ }^{93}$ Since it is unlikely that a person's stamen can be assimilated

93. Decisive - though probably not more than Athenagoras's similar claim that humans cannot assimilate human flesh, or Augustine's that all digested matter dissipates into the air. 


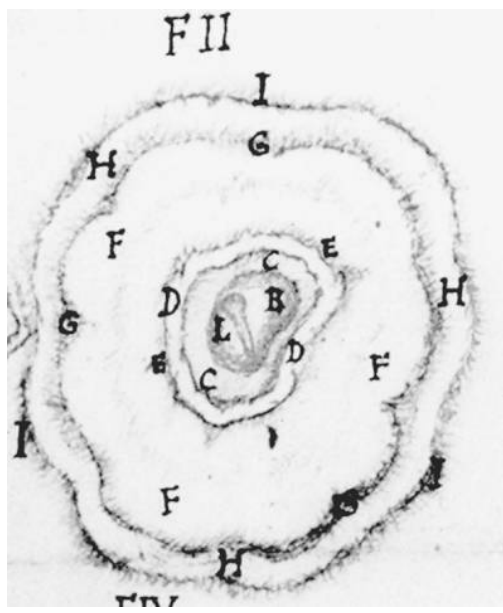

F I G U R E 2b. Detail of Malpighi’s drawing.

into another person's body, each stamen persists separately; and "it would likewise happen, according to the common Course of Nature, that the solid Particles divested of all their Juices, or the own Bodies of the devoured Person, would be discharged, or cast out unmingled with those of the Devourer; and consequently that each of them might appear separate and entire at the time of its Resurrection" ( $R P, 3: 1064)$. If cannibals only feed on "visible" bodies, then the food chain difficulty dissolves entirely. ${ }^{94}$

\section{Brains and Seminal Particles}

Although Nieuwentijt focused on the body, he constantly spoke of the person and made it clear that having an own body is the condition of possibility of personhood. He did not, however, confront the specifically psychological question of identity. For that, it was necessary to integrate physiology and psychology. Samuel Clarke, Newton's friend and advocate, did that in the Boyle lectures of 1704-1705. Immediately after stating that cannibalism was the "only real difficulty," he discarded it as "a great Trifle." For him, as for Boyle, it is not necessary "that, to constitute the same Body, there must be an exact Restitution of all and only the same Parts." One could of course imagine God preventing the substance of one human body from becoming the substance of another. In the light of contemporary embryology, Clarke felt the conjecture was superfluous.

94. The stamen theory, which may be called the germ theory of bodily identity, has a descendant in Saul Kripke's notion of the necessity of origin, according to which a person's identity is ultimately defined by genealogy; the one thing we cannot possibly be is the offspring of parents other than our own. See Saul Kripke, Naming and Necessity (Oxford, 1980). 
First, in a clear allusion to Malpighi, Clarke declared, "no Man can say 'tis probable that the original Stamina, which contain all and every one of the solid Parts and Vessels of the Body, not excepting even the minutest Nerves and Fibres, are themselves the intire Body." Strictly speaking, whatever comes from the outside to nourish the organism and make it develop is not itself part of the body. In contrast to this constantly fluctuating "extraneous Matter," the primal filaments persist unchanged; therefore, no "Confusion of Bodies" can ever take place, as was feared in the case of cannibalism. ${ }^{95}$

Clarke also used the preformation theory of generation. He explained that every organism contains a tiny "seminal Principle" that is itself the entire future organism. ${ }^{96}$ Perhaps our terrestrial body is nothing but the slough of one such hidden principle_- "(possibly the present Seat of the Soul) which at the Resurrection shall discover itself in its proper Form." ${ }^{97}$ Once again, regardless of the appearance resurrected bodies will assume, they will truly be the bodies of the persons to whom they belong. Boyle had stated that only a portion of the original matter is necessary for a resurrected body to be the same as a terrestrial body. As Nieuwentijt did a few years later, Clarke identified this portion with the filaments that, in Malpighi's embryology, function as the rudiments of mature organisms. The stamen thus constitutes the essence of the body's potential to express self.

The staminal hypothesis was extremely successful and inspired curious elaborations. In 1719 a collection appeared of Essays on Providence and on the Physical Possibility of the Resurrection. Published in French, its claim to have been "translated from the English of Dr. B." for a while turned Boyle into the presumed author. The book has been attributed to Jean-François Bion, a French priest who converted to Protestantism after being chaplain to Huguenot galériens. ${ }^{98}$ Bion's purpose was to elucidate Providence and

95. See Samuel Clarke, A Discourse Concerning the Being and Attributes of God, the Obligations of Natural Religion, and the Truth and Certainty of the Christian Revelation, 1oth ed. (London, 1768), p. 206.

96. As Malpighi, other seventeenth-century microcopists adhered to the preformation theory of generation that would dominate throughout the eighteenth century. Ovists, such as Jan Swammerdam, thought organisms were preformed in the egg; animalculists, that they were preformed as the "animalcules" Antoni van Leeuwenhoek had discerned in the sperm. In both cases, development consists in the unfolding or expansion of a preexisting form. The preformation theory was often accompanied by the idea of emboitement, or encapsulation, according to which all future generations of an organism exist within that organism's germ - the egg for the ovists, the sperm for the animalculists — ultimately back to Eve's egg and Adam's sperm.

97. Clarke, A Discourse Concerning the Being and Attributes of God, p. 207.

98. See Essais sur la Providence et sur la possibilité physique de la Résurrection, $2 \mathrm{~d}$ ed. (1719; Amsterdam, 1731); hereafter abbreviated E. After his conversion in 1704, Bion published a bestseller, Relation des tourments qu'on fait souffrir aux Protestants qui sont sur les galères de France (1708); he also translated Burnet's A Treatise Concerning the State of the Departed Souls; see Burnet, 
resurrection physiologically. The will, he explained, has no influence on bodily processes such as the circulation of the blood but can control others (for example, breathing) that are just as essential to life and as much governed by general and immutable laws. The reason why some functions can be voluntarily directed is that they depend on an excess of fluids, with which we are free to do what we want. It is the same, Bion claimed, with Providence. God originally put in nature fluids that lack a determinate function, and these he uses occasionally to alter the course of nature without suspending its laws (see E, p. 18). Thus could He stop the movement of the sun and the moon so that Joshua could defeat his enemies (see Josh. 10:12-13) or (a physico-theological favorite) make the iron axe float on the waters of the river Jordan.

In the case of the living world, Bion adds preformationism to the laws of moving matter and postulates that the germs of all beings were created by God at the beginning of life (see E, p. 16). The existence of these atomes organisés in the vegetable world is illustrated by an alchemical classic, the poppy that grows out of its planted ashes. As for animal germs, their significance for resurrection is that they are imperishable. How else could one explain the rain of tiny frogs the author claims to have seen in Languedoc and supposedly common in hot countries? Frogs lay their eggs in marshes; when water from these marshes evaporates, fertilized eggs rise with it; if they happen to end up in the clouds of a storm, they develop, and the result is a rain of minute, perfectly formed frogs (see $E$, pp. 34-36).

For Bion, then, germs are "the unraveling of the question about resurrection. For if men come from a germ, and this germ is imperishable and constitutes each man's fixed principle, then it will be no longer surprising that it take again a human form" (E, p. 226). Even more: the germ is "the true self" (le véritable moi; [E, p. 232]). After death, it will develop by processes akin to the dehydration and rehydration of frog's eggs. Now, generation was believed to require fermentation. Why? Because fermentation produces the "universal spirit" that functions as the "active cause" of generation ( $E$, p. 237) ${ }^{99}$ This explains why the raining frogs are so small; their germs receive such a sudden abundance of universal spirit that they attain perfection "in a minute" and have no time to reach their ordinary size.

Such is Bion's model for resurrection, one that makes "all the objections concerning the dogma ... fall by themselves" (E, p. 242). Fermentation?

Traité de l'état des morts et des résuscitans (Paris, 1731), and Tobias Swinden's An Enquiry into the Nature and Place of Hell (1714), under the title, Recherches sur la nature du fer de l'enfer: Et du lieu où il est situé (Amsterdam, 1757), a book that argues in favor of the reality and eternity of punishment by fire.

99. Spirit is here used in the chemical sense of a volatile substance (such as is produced by fermentation). 
Germs? Spirits? All the ingredients are there. Scripture, Bion claims, states that at the end of time the elements will be dissolved by heat. ${ }^{100}$

Consequently, there will be a strange fermentation, and hence a great abundance of universal spirit, which will be able, in an instant, to give all human germs a sudden and perfect growth. It [the result of this process] will be truly ourselves, since it will be our same germs, though with the difference that we will perhaps have none of the parts that previously composed our bodies. [E, p. 242]

Not all embryological arguments were as convoluted. In the early 1710s, the theologian Isaac Watts, a moderate Lockean and celebrated hymn writer, repeated the germ theory but emphasized that sameness required the "staminal particles" to be united to the same soul. As he wrote,

it seems that these unchanging Parts, whether few or many, in union with the same Soul, are abundantly sufficient to denominate Methuselah the Infant, and Methuselah the aged, the same person; and then also these few essential constituent Particles ... united to the same Soul, are sufficient to denominate Methuselah dying and Methuselah rising the same Person still, both Soul and Body. ${ }^{101}$

Staminal particles make the body self-identical. In 1728, the model was taken up in Chambers's Cyclopedia. By mid-century, Chambers's article was copied with modifications in Diderot's Encylopédie under the title "Résurrection," which also incorporated Locke's ideas on personal identity and presented the whole theory as something to be taken for granted.

The popularity of the germinal theory does not mean it went unquestioned. Thomas Broughton, an English divine, pointed out that, because stamina are made up of matter, they are as liable to dissolution and corruption as any other matter. ${ }^{102}$ As an alternative, he suggested that a body formed out of a corpse's residue, "without the Admixture of any foreign Matter," would be "the same Body" and that, out of any quantity of matter, God may form a complete body "for the Reception of the returning Soul."

100. Bion might have been thinking of the Apocalypse, where destruction by fire is the rule, and especially, perhaps, of Revelation 8:5-12 where, after an angel casts fire onto the earth, others start sounding trumpets, signaling the burning of trees and grass, the transformation of seas into blood and of other waters into wormwood, the death of living creatures, and the darkening of the stars.

101. Isaac Watts, “The Resurrection of the Same Body,” Philosophical Essays on Various Subjects, 3rd ed. (1713; London, 1742), pp. 191-92.

102. See Thomas Broughton, A Prospect of Futurity, in Four Dissertations on the Nature and Circumstances of the Life to Come: With a Preliminary Discourse on the Natural and Oral Evidences of a Future State; and an Appendix on the General Conflagration, or Burning of the World (London, 1768), pp. 189-90. 
Indeed, Broughton observed, "it is in the Power of God, out of a very small Remainder of the dead Body, to form, by Dilatation, Expansion, or Rarefaction, a Body of equal Size and Dimension, though not of equal Density, with That, which was laid in the Grave." ${ }^{103}$ Like Burnet almost a century earlier, Broughton emphasized the ethereal nature of the resurrected body. But, even at that point of spiritization, some material vestige of the original was deemed necessary.

\section{The Enlightenment Climax: Embryo-neuro-psycho-theology}

Compared to purely embryological models, Clarke's theory was highly innovative. For him, the bodily remnant out of which the resurrected body would evolve was an imperishable organic structure that functioned not only as a seminal developmental principle but also as the seat of the soul. Such a structure, therefore, would operate as the basis of bodily and psychological identity alike, as the material foundation of both the embodied self and the "enselved" body. Whether or not Clarke was the first to formulate it, the combination of embryological germ and seat of the soul was found convincing by, among others, two major figures in the history of eighteenth-century psychology and philosophy, David Hartley and Charles Bonnet. ${ }^{104}$

The second part of Hartley's Observations on Man is often overlooked. The well-known first part elaborates an associationist psychology based on the theory of vibrations and "vibratiuncles" of the nerves. The forgotten second part is an apologetic treatise of morality and natural religion. And it is here that Hartley, in an attempt to render the resurrection intelligible, postulates the existence of an "elementary infinitesimal body in the embryo." This body has the double function of receiving sensations and bringing about organic development. After death, he explains, it subsists, retains "its power of vegetating again," and thus makes possible the development of a resurrected body. ${ }^{105}$ Again, body is indispensable for self, since, Hartley writes, "neither the elementary body, nor the immaterial principle, which is generally supposed to preside over this, can exert themselves without a set of suitable organs." 106

103. Ibid, pp. 194-95, 200.

104. Their speculations fit into a larger context of Enlightenment physico-theology; see Fernando Vidal, "Extraordinary Bodies and the Physico-theological Imagination," in Nature on Display in Eighteenth-Century Europe, ed. Gianna Pomata and Lorraine Daston (forthcoming). This article is available as preprint no. 188 of the Max Planck Institut für Wissenschaftsgeschichte (Berlin, 2001).

105. David Hartley, Observations on Man, His Frame, His Duty, and His Expectations, 6th ed. (1749; London, 1834), pp. 559, 560 .

106. Ibid., p. 571. 
The fullest and most remarkable speculations on the subject are to be found in the work of the Genevan naturalist and philosopher Charles Bonnet. ${ }^{107}$ Author of important investigations in natural history and of a philosophical system that combines Lockian sensationism with Leibnizian metaphysics, Bonnet gave the problem of resurrection a central place in his thinking and life (fig. 3). ${ }^{108} \mathrm{His}$ argument can be summarized in the following way: Humans are composed of body and soul; they can therefore survive only as mixed beings. ${ }^{109}$ Personal identity depends on memory (Locke's theory), and memory is based in the brain. It follows that, if man is to keep his identity in the afterlife, his soul must remain united to some indestructible organ, perhaps the same that functions as the seat of the soul. ${ }^{110}$ Bonnet describes it as a "little ethereal machine" and as an "indestructible brain" encased in the brains of our terrestrial bodies. In addition to being the seat of the soul, the little machine is the germ of resurrected bodies. ${ }^{111}$ It will therefore act in truly embryological fashion, producing bodies in accordance with the preformationist emboitement theory of generation.

In short, our present brains enclose another brain, destined to develop in the afterlife and to restore our identity, personality, and body together. ${ }^{12}$ Since the resurrected body will be spiritual and incorruptible, the "small human body" hidden in the seat of the soul must be physically different from our bodies of flesh. Indeed, it is "that spiritual body which Revelation contrasts to the animal body that is only its envelope." ${ }^{113}$ But differences are secondary. Although body as such is essentially for identity, it is not through the numerical sameness of terrestrial and spiritual bodies that human beings will prolong their earthly past. Hence the limits of psycho-theology. "The psychologist," Bonnet wrote of himself, "who treats of human permanence [after death] must investigate analytically how the future state will relate to the past state, and by what physical means man will conserve his

107. I will use Charles Bonnet, Oeuvres d'histoire naturelle et de philosophie (Neuchâtel, 1781). Bonnet's exposition of his ideas is rather repetitive and can be found elsewhere in his work, especially in Palingénésie philosophique (1769; see vol. 7 of Oeuvres) and Recherches philosophiques sur les preuves du christianisme (1770).

108. The centrality of resurrection in Bonnet's thought has not been studied in detail but is recognized by Max Grober, "The Natural History of Heaven and the Historical Proofs of Christianity: La Palingénésie philosophique of Charles Bonnet," Studies on Voltaire and the Eighteenth Century 308 (1993): 233-55. See also Roselyne Rey, "La Partie, le tout et l'individu: Science et philosophie dans l'oeuvre de Charles Bonnet," and Vidal, "La Psychologie de Charles Bonnet comme 'miniature' de sa métaphysique," in Charles Bonnet, savant et philosophe (17201793), ed. Marino Buscaglia et al. (Geneva, 1994), pp. 61-76, 43-50.

109. See Bonnet, Essais sur la vie à venir (Paris, 1828), p. 8.

110. See Bonnet, Mémoires autobiographiques de Charles Bonnet de Genève, ed. Raymond Savioz (Paris, 1948), p. 238; hereafter abbreviated MA.

111. Bonnet, Contemplation de la nature (1764), Oeuvres, 4:1:139, n. 5.

112. See Bonnet, Essai analytique sur les facultés de l’âme (1760), Oeuvres, vol. 6, \$730.

113. Ibid., $\$ \$ 745,747$. 


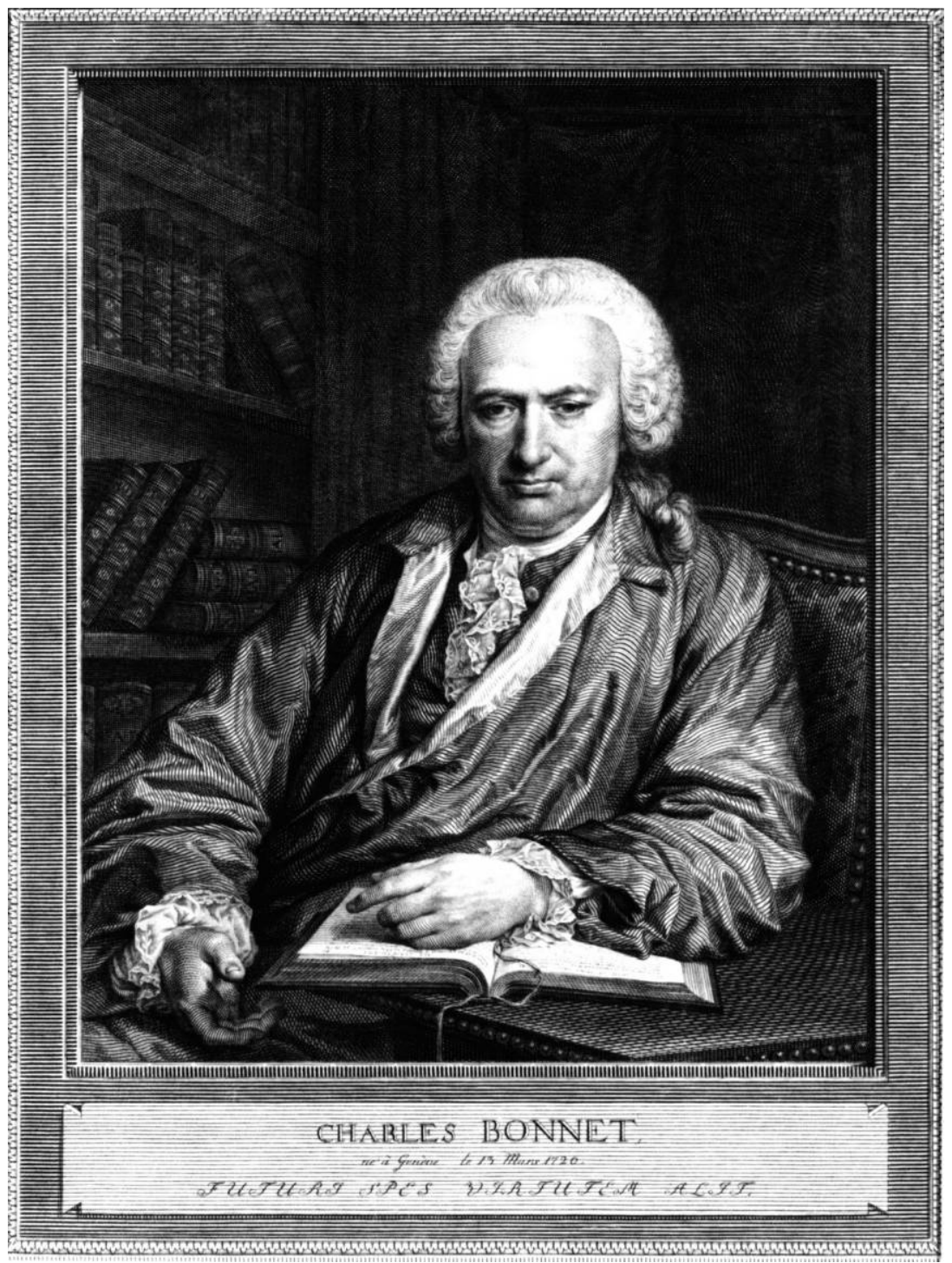

F I G U R E 3. Engraved frontispiece of Charles Bonnet, Oeuvres d'histoire naturelle et de philosophie (Neuchâtel, 1781), after a 1777 oil painting by Jens Juel. The Genevan naturalist and philosopher Bonnet (1720-93), meditating (as he explained) on the "future restoration and perfecting of living beings," with the Gospels open at 1 Cor. 15:36 and 15:35: "ce que vous semez ne reprend point la vie, s'il ne meurt auparavant-O mort, où est ton aiguillon? ô Sépulcre, où est ta victoire?" ("that which thou sowest is not quickened, except it die- $\mathrm{O}$ death, where is thy sting? $\mathrm{O}$ grave, where is thy victory?"). The plaque reads, "CHARLES BONNET né à Genève le 13 Mars 1720. FUTURI SPES VIRTUTEM ALIT" ("The hope of the future sustains virtue"). Photography: Centre d'Iconographie Genevoise (Geneva). 
personality and all the knowledge [connaissances] he acquired in his terrestrial state" (MA, p. 324). ${ }^{114}$

Leonhard Euler, the Basel mathematician, found Bonnet's "little ethereal machine" too fragile. If a physical accident can shatter our memory-and therefore our personality - at a time when the "machine" is encased within our brains of flesh, how will this ethereal organ subsist undamaged after death, when it will be no longer protected? Were it destroyed, the personality itself would suffer the same fate; and the soul would have to be preserved by an implausible continuous miracle (see MA, pp. 292-93). Bonnet replied that he did not base the immortality of the soul on the "small organic machine." Rather, since the soul is not the "whole man," its union to an organic structure is indispensable. The Gospels, he observed, do not speak of the immortality of soul, but of man. If they did, resurrection would be meaningless. "Que signifierait la Résurrection, si l'âme était tout l'homme?" (MA, p. 301). That is why, for Bonnet, Saint Paul was l'apôtre philosophe (MA, p. 246). The "key to the philosophical explanation" of such Christian dogmas as the incarnation and resurrection was the fact that they concern the "mixed nature of our being" (MA, p. 360). And the key to our mixed nature is furnished by the brain. Anatomical debates on the seat of the soul in the brain are therefore relevant for discussing resurrection.

Bonnet, who was perfectly aware of those debates, was not interested in determining an exact location. He left the job to physiologists but remarked that, whatever their opinions, the "immediate" instrument of the operations of the soul must be a single, unitary organ. ${ }^{115}$ The significance of this anatomical requirement explains Bonnet's reaction to the Italian anatomist's Vincenzo Malacarne's observation that nerves entering the brain do not converge onto a single location. Bonnet, whose psychological writings inspired the anatomist, initially accepts he might be wrong. ${ }^{116}$ Later, however, he admits his reluctance to give up all convergence and emphasizes that the soul cannot be present simultaneously throughout the nervous system. "Excuse me," he tells Malacarne, "if I insist on this point: you see well enough that the Palingénésie you love is based a little on that seat of the soul that your anatomical research very much undermines." ${ }^{117}$ In short, for Bonnet, the possibility of the resurrection as full restitution of bodily and per-

114. Analytically, that is, from observation and experience, as opposed to "synthetically," by deduction from principles and axioms.

115. Bonnet, Contemplation de la nature, 4:1:138-39n.

116. "Lettres à Monsieur Vincent Malacarne," Lettres sur divers sujets d'histoire naturelle, in Bonnet, Oeuvres, 5:2:394.

117. Ibid., p. 397. 
sonal identity depends on a cerebro-germinal particle whose existence is incompatible with the dispersion of soul in different brain locations. ${ }^{118}$

\section{What Is Left?}

We have witnessed a gradual disembodiment. When Bonnet made the embryology of the resurrected body and the developmental neuropsychology of personal identity coincide, he imagined that the "germ" of the resurrected body was a brain. Voltaire was sarcastic, but not inaccurate, when he wrote that the Genevan "seems persuaded that our bodies will resurrect without a stomach, and without the front and rear parts, but with intellectual fibers and excellent intellects." ${ }^{119}$ Boyle concluded that only a portion of the terrestrial body's matter was necessary to form resurrected bodies; Leibniz spoke of a mysterious substantiae flos; Locke reduced personal identity to psychological continuity; Clarke speculated that the seminal fibers of the glorious body were also the seat of the soul; and by giving this primordial structure the shape of a brain, Bonnet accomplished the tendency to minimize the place of flesh and to replace the resurrection of the body by a resurrection of brain-located psychological identities. This disincarnating trend will have to be connected to the emergence of liberal Protestantism ${ }^{120}$ as well as to the changes in attitudes toward life and death that marginalized traditional doctrines and beliefs about the resurrection. ${ }^{121}$ The

118. The fact that Watts, Hartley, and Bonnet were praised by the English chemist and religious controversialist Joseph Priestley for their germ theory of resurrection highlights how broad the margins for maneuvering in the physico-theological field were. Priestley asserted the materiality of the soul, denied its immortality, and (in analogies that explicitly concerned personal identity) affirmed that we are as entirely composed of matter as a river of water or a forest of trees. For all intents and purposes, he said, we shall at resurrection be the same we were on earth if "we shall all know one another again, and converse together as before" (Joseph Priestley, Disquisitions Relating to Matter and Spirit and the Doctrine of Philosophical Necessity Illustrated [1777; New York, 1976], p. 160).

119. Voltaire, Dieu et les hommes, oeuvre théologique mais raisonnable (1769), ed. Roland Mortier, in vol. 69 of Les Oeuvres complètes de Voltaire (Oxford, 1994), p. 454.

120. For Immanuel Kant, a foundational figure of liberal Protestantism, the immortality of the soul is a postulate of pure practical reason, and the resurrection of Jesus, a legend in which Saint Paul would not have believed had it not served as a morally necessary proof of a future life. From the moral point of view (to which Kant reduces religion), it is irrelevant whether the terrestrial body is necessary for personal identity in the afterlife or even whether our bodies will be resurrected. See Immanuel Kant, The Conflict of the Faculties (1798), trans. Mary J. Gregor (Lincoln, Nebr., 1992), where Kant formulates principles of scriptural exegesis aimed at solving the conflict between the faculties of philosophy and theology.

121. In the eighteenth century, allusions to bodily resurrection disappear from wills, the funerary ritual in which the presence of the dead body symbolically recalls its organic link to the soul is given up, and the resurrection of the body is no longer a vehicle for the speculative or poetical expression of desires of immortality and eternity. See Michel Vovelle, Piété baroque et déchristianisation en Provence au XVIIIe siècle: Les Attitudes devant la mort d'après les clauses des 
body was henceforth relevant only as a physical basis of the psychological features deemed necessary for personal identity.

"On ne se détache pas du merveilleux, quand une fois on lui a donné sa créance, et pendant longtemps on s'acharne à rationaliser la merveille plutôt qu'à la réduire." 122 Gaston Bachelard's astute observation on the difficulty of dissolving wonder may sum up the history of attempts at naturalizing the resurrection. Yet the raising of the dead is a special case. It may be, if it ever happens, the wonder of wonders, but it also stands apart from the natural and preternatural marvels the Enlightenment sought to discredit and domesticate. ${ }^{23}$ The criteria of testimony used to judge miracles or extraordinary phenomena can apply only indirectly to an event supposed to be outside time and space and one supposed to signal the end of nature and the universe. Although the intrinsic plausibility of resurrection could be questioned, belief in its probability or certainty did not count as the superstitious or "enthusiastic" product of a diseased imagination. The Enlightenment contributed to make the miraculous less prominent in theology and faith and to leave it behind as a silent and unsettled question on the edges of culture, ignored, like marvels, rather than debunked. In the process, the body was lost.

What became implausible was not resurrection as such but the resurrection of the (same) body. Such a judgment stimulated the proposition of alternatives that deeply altered the landscape of belief. By the end of the eighteenth century, the psychological problem of personal identity had triumphed over the numerical sameness of bodies. Disembodiment thus sustained the doctrines of metempsychosis that, since the nineteenth century, have dominated over traditional Christian eschatology. ${ }^{124}$ Yet, on the margins of this transformation, and independently of other discussions on the persistence of personality after death, debates took place during the nineteenth and twentieth centuries on the relations between the resurrection of the flesh and scientific models and data. A version of the germ theory was

testaments (Paris, 1973); Pierre Chaunu, La Mort à Paris: XVIe, XVIIe et XVIIIe siècles (Paris, 1978); and Robert Favre, La Mort dans la littérature et la pensée françaises au siècle des Lumières (Lyon, 1978), chap. 12.

122. "We do not turn away from wonder once we have given it credence, and for a long time we strain to rationalize wonders rather than to reduce them" (Gaston Bachelard, La Formation de l'esprit scientifique: Contribution à une psychanalyse de la connaissance objective, 11th ed. [1938; Paris, 1980], p. 108).

123. See Daston and Katharine Park, Wonders and the Order of Nature, 1150-1750 (New York, 1998), chap. 9.

124. See Louis-Vincent Thomas, "L'Eschatologie: Permanence et mutation," in Thomas et al., Réincarnation, immortalité, résurrection (Bruxelles, 1988), pp. 1-42. 
proposed in 1888; a century later, it was imaginable that DNA and raw materials could suffice to bring about the resurrection of the body. ${ }^{125}$

Successive amputations of the body have been accompanied by an increasing precision concerning the part of flesh necessary for personal identity. Initially, there was an indeterminate portion of matter, which early on adopted the form of a seminal particle. Because embryology alone was incapable of accounting for identity, the seminal particle assumed some features of the brain. Endowed with a double function, the "germ" was entirely responsible for the postmortem development of resurrected persons as psychosomatic unities. But why bother with the body? All we need for Judgment Day is an accountable and conscious personality. To the extent that the brain is responsible for it, why not limit resurrection to the brain? And why not go a step further? If only part of the brain is necessary to be a person, shall we need it whole to enjoy the beatific vision? ${ }^{126}$ Maybe just a fraction will suffice. This fraction will have to contain the information necessary for defining the self. A computer program might therefore be enough. The resurrected $I$ need be nothing other than the computer equivalent of my brain. In this way, thanks to the progress of technology, to resurrect might eventually mean to be emulated by supercomputers; thus resurrected, we shall inhabit a hereafter whose technical name is cyberspace. ${ }^{127}$ But how much can "we" disembody ourselves without becoming simulacra? Are we still "us" in a state of "postorganic" immortality? ${ }^{28}$

I see in the story sketched here at least two lessons to be drawn. One is methodological. When looked at from within philosophy, the history of the self tends to study the history of notions of the self; and it is further supposed that such notions, when not explicitly formulated, can be inferred from philosophical texts. Self thus appears to be a transhistorical object whose manifestations and metamorphoses the philosopher-historian can apprehend. It is in this vein that Paul Ricoeur remarks that the question of identity has always generated interest in puzzle cases and that humans have always been intrigued by religious beliefs about transmigration, immortality, and

125. See Marc Thury, "Le Dogme de la résurrection et les sciences de la nature," Revue chrétienne 4 (1888): 573-81, and Marcel Bessis, "Une Version athée de la résurrection des corps," in Soi et non-soi: Des biologistes, médecins, philosophes, et théologiens s'interrogent, ed. Jean Bernard,

Marcel Bessis, and Claude Debru (Paris, 1990), pp. 261-65.

126. See Detlef Bernhard Linke, "Gehirn, Seele, und Auferstehung," Evangelische Theologie 50 (1990): 128-35, esp. pp. 133-35.

127. See Frank J. Tipler, The Physics of Immortality: Modern Cosmology, God, and the Resurrection of the Dead (New York, 1994), chap. 9.

128. For curious reflections on the dissolution of the biological body and its incorporation into the information body, see Knowbotic Research, "Postorganic Immortality: Vom Körper zu 'Incorporations,” Kunstforum 133 (Feb.-Apr. 1996): 161-65. 
resurrection. ${ }^{129}$ By implying that such beliefs exist as puzzle cases about a preexisting underlying question, Ricoeur turns around what I take to be their significance. Discussions about transmigration, immortality, or resurrection were not epiphenomenal expressions of a latent interest in the question of identity; they were, I would argue, consubstantial to that interest itself.

Even when looked at from within history (and to the extent that it is possible to give a single name to a prodigiously diversified field), the ontological basis of self sometimes seems to transcend historical contingency. This is not because it is thought to be stable across time but because it is seen as represented, expressed, or legitimized—rather than actually madethrough diverse "life-writing" and self-dramatization pratices, such as confessions, memoirs, autobiographies, as well as novels and biographies. ${ }^{130}$ There is, of course, a large field of studies about the formation of embodied selves (individual, gendered, racial, and so on). ${ }^{131}$ In its most Foucauldian version, the history of the self deals with a "genealogy of subjectification" that, in Nikolas Rose's words,

focuses directly on the practices that locate human beings in particular "regimes of the person." It does not write a continuous history of the self, but rather accounts for the diversity of languages of "personhood" that have taken shape-character, personality, identity, reputation, honor, citizen, individual, normal, lunatic, patient, client, husband, mother, daughter-and the norms, techniques, and relations of authority within which these have circulated in legal, domestic, industrial, and other practices for acting upon the conduct of persons.

The object of genealogy is neither changing ideas of the person, nor the person as psychological entity, but the largely "technical" disciplines of mind and body whereby "human beings come to relate to themselves and others as subjects of a certain type." 132 These techniques are not applied to

129. “La question de l'identité a toujours suscité l'intérêt pour des cas paradoxaux. Les croyances religieuses et théologiques relatives à la transmigration des âmes, à l'immortalité, à la résurrection de la chair, n'ont pas manqué d'intriguer les esprits" (Ricoeur, Soi-même comme un autre, pp. 160-61).

130. For recent examples, see Representations of the Selffrom the Renaissance to Romanticism, ed. Patrick Coleman, Jayne Lewis, and Jill Kowalik (Cambridge, 200o); see also Michael Mascuch, Origins of the Individualist Self: Autobiography and Self-Identity in England, 1591-1791 (Cambridge, 1997).

131. For recent examples, see "Identity, Self, and Subject," a special issue of History of the Human Sciences 7 (May 1994); see also Rewriting the Self: Histories from the Renaissance to the Present, ed. Porter (London, 1997).

132. Nikolas S. Rose, "How Should One Do the History of the Self?" Inventing Our Selves: Psychology, Power, and Personhood (New York, 1996), p. 25. 
the self but constitutive of it. This does not mean that human beings do not exist independently of those techniques but that, as highlighted by Ian Hacking's "dynamic nominalism," part of what we effectively are and do is connected with our descriptions. ${ }^{133}$

The constructionist Foucauldian orientation poses a challenge opposite to that of the philosophical. Philosophers' narratives focus on the concept of self or on discourses from which the concept can supposedly be inferred. Historians, in contrast, tend to overlook the concept, as if its history qua concept played no role in instituting the regimes of the self. Although I do not assume an underlying perennial self, what I have done here is obviously closer to the history of ideas than to genealogy. Nevertheless, I want to suggest that concepts have their own efficacy and should be incorporated into genealogy as active agents. In the same way that, say, child-rearing techniques are not about the self nor applied to it as a preexisting object, debates about the resurrection of the body were not about identity, nor were the issues discussed in connection with them contemplated as puzzle cases in the philosophy of mind. Rather, they were among the materials with which notions of identity were elaborated and through which, historically, such notions came into existence. This became apparent in the wake of Locke's Essay Concerning Human Understanding, when the resurrection of the body was explicitly linked to personal identity. The "modern" regimes of self, and the corresponding ways of experiencing oneself, were thus connected to the development of new concepts of the self. The redefinition of the resurrected identity belonged in the construction of new models of being based less on the hierarchical subordination of the body to the soul than on a generative subordination of selfhood to the brain and to an objectified self-consciousness. The glorious body was no longer necessary as ideal for the discipline of terrestrial bodies. ${ }^{34}$ The story sketched here thus suggests the need for bringing the history of ideas and the genealogy of subjectification together into an approach that will ultimately do for personal identity what historical epistemology is doing for the history of objectivity. ${ }^{135}$

133. See Ian Hacking, "Making up People," in Reconstructing Individualism: Autonomy, Individuality, and the Self in Western Thought, ed. Thomas C. Heller, Morton Sosna, and David E. Wellbery (Stanford, Calif., 1986), pp. 222-36.

134. This remark is inspired by Jérôme Baschet's emphasis on the "spiritual body" as a duality characterized by the domination of the soul over the body and by the body's elevation through submission to the soul. As a model for the authority of the clergy over secular society, such a hierarchical and dynamic union appears as a fundamental ideological and social matrix in Medieval Latin Christendom. See Jérôme Baschet, "Ame et corps dans l'occident médiéval: Une Dualité dynamique, entre pluralité et dualisme," Archives de sciences sociales des religions 112 (2000): 5-30, esp. pp. 19-26.

135. See Daston and Peter Galison, “The Image of Objectivity," Representations, no. 40 (Fall 1992): 81-128, and Daston, "L'Invention de l'objectivité," Cahiers de Science and Vie, no. 48 (Dec. 
A second lesson might be called inspirational. The idea of resurrection participated in the political functions of hell. ${ }^{136}$ Whether it is best considered, with Freud, as a symptom of a universal neurosis or, with Jankélévitch, as a form of the "hopeless optative," it has played, for those who believe in it, an important existential role. ${ }^{137}$ But political and psychological functions do not exhaust its historical meaning. Two millennia after its initial formulation, the Christian doctrine of the resurrection has a potential to question and to move that is more powerful and profound than considerations of wandering little fingers or hypothetical brain transplants. Resurrection discourses differ fundamentally from philosophical thought experiments. ${ }^{138}$ Indeed, they were not seen as concerning fantastical situations from which apparently relevant conclusions could be extracted but as meaningful matters of momentous real consequences. One of them was the certainty that bodies are essential to humanity and that a disembodied self does not rank as a human being. Thus, while the neuropsychological eschatologies science and philosophy produced since the seventeenth century moved us away from the Middle Ages, our era's questions and dilemmas about self and body take us back. In its own way, the Christian romance of the resurrection, with its assertion of the ontologically crucial place of body for identity and of community for human existence, may still be an inspiring story for those who, against the neurological reduction of self, would rather live with body, desire, history, and the other than inhabit the solitude of isolated brains.

1998): 16-23. For somewhat more programmatic statements about historical epistemology, see Daston, "Une Histoire de l'objectivité," Des Sciences et des techniques: Un Débat, ed. Roger Guesnerie and François Hartog (Paris, 1998), pp. 115-26. And for a study that points in the direction I'm thinking about, see Jan Goldstein, "Mutations of the Self in Old Regime and Postrevolutionary France," in Biographies of Scientific Objects, ed. Daston (Chicago, 20oo). See also Arnold I. Davidson, The Emergence of Sexuality: Historical Epistemology and the Formation of Concepts (Cambridge, Mass., 2001).

136. In the seventeenth and eighteenth century, at a time when the idea of eternal punishment loses ground in dogmatic theology, divines insist on keeping it as a tool for the maintenance of moral and social order. See Daniel Pickering Walker, The Decline of Hell: Seventeenth-Century Discussions of Eternal Torment (Chicago, 1964). Something analogous took place for the resurrection. As Bunyan warned, "he that denyeth the Resurrection of the dead, he setteth open a Floud-gate to all manner of impiety, he cutteth the throat of a truly holy life, and layeth the Reins upon the neck of the most outragious lusts" (Bunyan, The Resurrection of the Dead, p. 214).

137. Optatif désespéré: "optative" is that which expresses wish, desire, hope. See Vladimir Jankélévitch, La Mort (Paris, 1977), p. 381.

138. For an illuminating discussion and critique, see Kathleen V. Wilkes, Real People: Personal Identity without Thought Experiments (Oxford, 1988), esp. chap. 1. 